\title{
Water Quality and Aquatic Toxicity Data of 2002 Spring Thaw Conditions in the upper
}

\section{Animas River watershed, Silverton, Colorado}

By D.L. Fey, L. Wirt', J.M. Besser, and W.G. Wright ${ }^{3}$

${ }_{2}^{1}$ U.S. Geological Survey, Denver, Colorado

${ }_{3}^{2}$ U.S. Geological Survey, Columbia, Missouri

U.S. Geological Survey, Durango, Colorado

Open-File Report 02-488

2002

This report is prelininary and has not been reviewed for conformity with U.S. Geological Survey editorial standards or with the North American Stratigraphic Code. Any use of trade, firm, or product names is for descriptive purposes only and does not imply endorsement by the U.S. Government.

U.S. Department of the Interior

U.S. Geological Survey 


\section{Contents}

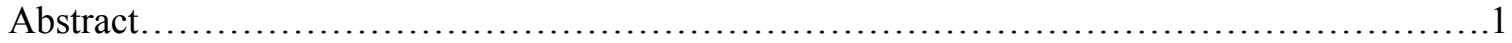

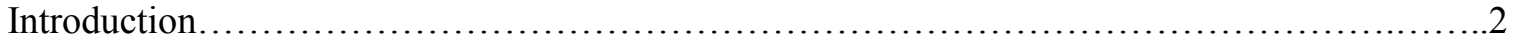

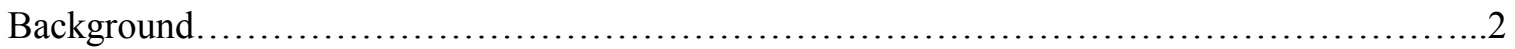

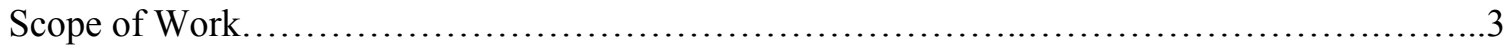

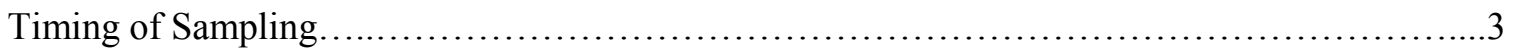

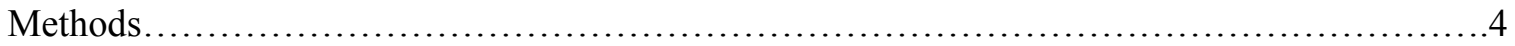

Water Quality...........................................................4

Sample Collection........................................................

Water-Chemistry Analyses................................................

Aquatic Toxicity.........................................................6

Sample Collection................................................6

Aquatic Toxicity Analytical Methods....................................6

Water-Quality Results.........................................................6

Aquatic Toxicity Results........................................................ 13

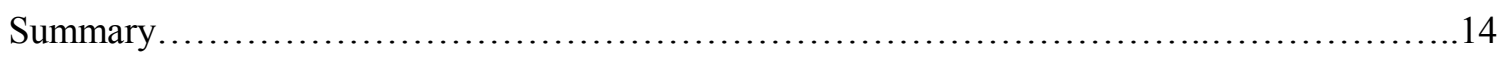

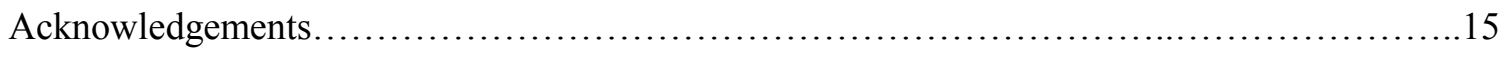

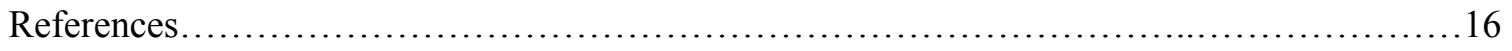

\section{List of Figures}

Figure 1. Locality map of streamwater and toxicity sampling sites, upper Animas River,

Colorado..................................................................

Figure 2. Discharge of Animas River at A-72 gage from early March to early May 2002........5

Figure 3. Discharge and turbidity over the sampling period March 27-30, 2002 _..............7

Figure 4. Concentration curves for calcium and strontium over the sampling period March 27-30, 2002 ..................................................

Figure 5. Concentration and load curves for sulfate over the sampling period March 27-30,

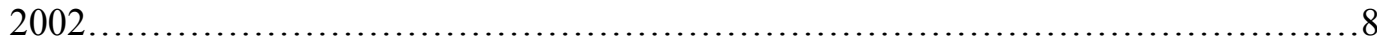

Figure 6. Concentration and load curves for aluminum over the sampling period March 27-30,

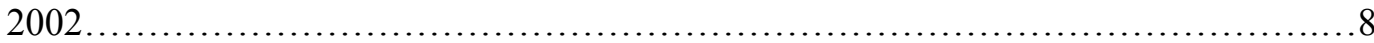

Figure 7. Concentration and load curves for silicon over the sampling period March 27-30,

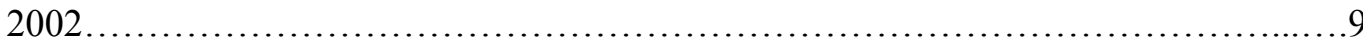

Figure 8. Concentration curves for total-recoverable iron, dissolved ferrous iron, dissolved ferrous plus ferric iron, with turbidity curve for comparison. 
Figure 9. Concentration and load curves for total-recoverable-iron over the sampling period

March 27-30, 2002.....................................................11

Figure 10. Concentration and load curves for copper over the sampling period March 27-30,

2002

Figure 11. Concentration and load curves for lead over the sampling period March 27-30,

2002

Figure 12. Concentration and load curves for zinc over the sampling period March 27-30,

2002 .

Figure 13. Toxicity of stream water and dilutions from the Animas River at A-72 to

amphipods

Figure 14. Toxicity of stream water and dilutions from the Animas River at A-72 to minnows

\section{List of Tables In Appendix}

Table A1. Field numbers, date, time, discharge, conductivity, $\mathrm{pH}$, temperature, hardness, alkalinity, turbidity, ferrous iron, ferrous plus ferric iron, and fluorine, chlorine, and nitrate concentrations of water samples, Animas River water samples from A-72 gage, March 27-30, 2002.

Table A2. Field numbers, date, time, discharge, conductivity, $\mathrm{pH}$, temperature, hardness, alkalinity, turbidity, ferrous iron, and fluorine, chlorine, and nitrate concentrations of water samples, Cement Creek, Mineral Creek, and upper Animas River, March 27-30, 2002 .

Table A3. Date, time, discharge, and major and trace element data for unfiltered water at gage station A-72, Animas River below Silverton, March 27-30,

2002

Table A4. Date, time, discharge, and major and trace element data for unfiltered water samples from Cement Creek, Mineral Creek, and upper Animas River, March 27-30, 2002

Table A5. Quality control data for unfiltered water samples collected from Animas River, Cement Creek, and Mineral Creek near Silverton, Colorado, March 27-30, 2002 ..............A6

Table A6. Survival of amphipods (Hyalella azteca) and fathead minnows (Pimephales promelas) in serial dilutions of stream water collected at gage station A-72, Animas River below Silverton, March 22-27 (Test 1), March 28-29 (Test 2), and May 1-6 (Test 3).........A8 


\title{
Water Quality and Biological Toxicity Data of 2002 Spring Thaw Conditions in the upper Animas River watershed, Silverton, Colorado
}

\begin{abstract}
This report presents hydrologic, water-quality, and biologic toxicity data collected during the annual spring thaw of 2002 in the upper Animas River watershed near Silverton, Colorado. The spring-thaw runoff is a concern because elevated concentrations of iron oxyhydroxides can contain sorbed trace metals that are potentially toxic to aquatic life. Water chemistry of streams draining the San Juan Mountains is affected by natural acid drainage and weathering of hydrothermal altered volcanic rocks and by more than a century of mining activities. The timing of the spring-thaw sampling effort was determined by reviewing historical climate and streamflow hydrographs and current weather conditions. Twenty-one water-quality samples were collected between 11:00 AM March 27, 2002 and 6:00 PM March 30, 2002 to characterize water chemistry at the A-72 gage on the upper Animas River below Silverton. Analyses of unfiltered water at the A-72 gage showed a relation between turbidity and total-recoverable iron concentrations, and showed diurnal patterns. Copper and lead concentrations were related to iron concentrations, indicating that these elements are probably sorbed to colloidal iron material. Calcium, strontium, and sulfate concentrations showed overall decreasing trends due to dilution, but the loads of those constituents increased over the sampling period. Nine water-quality samples were collected near the confluence of Mineral Creek with the Animas River, the confluence of Cement Creek with the Animas River, and on the upper Animas River above the confluence with Cement Creek (three samples at each site). A total of six bulk water-toxicity samples were collected before, during, and after the spring thaw from the Animas River at the A72 gage site. Toxicity tests conducted with the bulk water samples on amphipods did not show strong differences in toxicity among the three sampling periods; however, toxicity of river water to fathead minnows showed a decreasing trend during the course of the study.
\end{abstract}




\section{Introduction}

The initial spring thaw or early rising limb of the snowmelt cycle typically produces highly turbid water. This is a particular concern in the highly mineralized upper Animas River watershed (fig. 1), containing hundreds of inactive prospects and mines, and characterized by naturally acidic drainage from a hydrothermally-altered volcanic complex. Water quality of alpine watersheds is highly seasonal and can change rapidly over short periods ranging from hours to days, particularly in response to warm weather that produces snowmelt runoff or to episodic storm runoff (Wirt and others, 2000; Leib and others, 1999; Sullivan and Drever, 2001). Local observers describe a spring thawing period when streams are highly turbid and turn orange-brown for a few days to a week during late March or early April. The color of the water is indicative of suspended iron hydroxides that form in acid drainage environments. Iron-oxide material can sorb and transport potentially toxic metals in the solid phase (Smith, 1999; Church and others, 1997; Horowitz and Elrick, 1987). Better understanding of this phenomenon is needed to determine whether this short-lived flush of iron hydroxides in the initial pulse of snowmelt may be a critical limiting factor for stream biota by mobilizing high concentrations of toxic metals (Besser and Leib, 1999; Besser and others, 2001).

Snowmelt occurs when the snow pack becomes isothermal and melted water percolates through the snow pack. In a mineralized watershed such as the Animas River watershed, metalrich salts, iron hydroxides, and fine particulates stored during winter are mobilized from the soil zone. In addition, amorphous, colloidal iron-hydroxide material that formed in the water column and settled to the streambed or was deposited on stream banks during the low flow winter conditions can be mobilized by the increase in flow. The highest turbidity values are typically measured during these early stages of snowmelt and also in the runoff from large rainstorms (Wirt and others, 2000; Nimick and others, 2002). In the early stages of snowmelt, the turbidity is positively correlated with diurnal variations in stream-flow discharge. This is in contrast with the clear, relatively sediment-free discharge of winter base flow. Later in the cycle, the relatively pure snowmelt dominates the hydrograph and dilutes the diminishing fraction of more concentrated base flow that is derived from ground water. In this report we define the "spring thaw" phenomenon as the highly turbid, initial rising limb of the hydrograph resulting from the first pulse of snowmelt, which can last several days or longer.

Few time-series data have previously been available to describe this brief transitional period between late winter base flow and the early snowmelt runoff - in part because of the forecasting and logistical difficulties of collecting such a dataset. Thus, we sought to characterize the variation in total metal concentrations and iron hydroxides, and the toxicity of the turbid water during this time period. This report presents water-quality and biologic toxicity data that were collected during the spring thaw of 2002 in the upper Animas River watershed near Silverton, Colorado.

\section{Background}

Since 1994, the USGS has been cooperating with the Animas River Stakeholders Group to characterize the effects of historical mines on the environment and to describe the occurrence of pre-mining concentrations of metals in the watershed. In 1997, the USGS started the Department of the Interior Abandoned Mine Lands (AML) Initiative in the upper Animas River watershed. The goal of the AML Initiative is to supply scientific information needed to develop cost-efficient remediation strategies for clean up of historical mine lands on Federal land in the western US. The spring thaw phenomenon was identified through analysis of data collected as part of AML, and an understanding of the event was identified as a data gap that needs to be addressed in the watershed. 


\section{Scope of Work}

The objectives of this study were 1) to collect and analyze a time-series set of water chemistry samples during the spring thaw, and 2) to conduct toxicity testing of amphipods and minnows with Animas River water.

The study approach was to collect a time-series set of water samples at the A-72 gage of the Animas River below Silverton, Co. for chemical and toxicity analysis that are representative of spring thaw conditions. A total of thirty water-quality samples were collected from the Animas River and its tributaries near Silverton, Colorado during a 4-day period of high the turbidity that is characteristic of the spring thaw. The A-72 gage was selected as an integrator site for the Animas River watershed, owing to its position downstream from the confluence of the upper Animas River with Cement Creek and Mineral Creek (Fig. 1). Stream stage, discharge, water temperature, $\mathrm{pH}$, specific conductance, and turbidity were measured at the continuous monitor probe at the Animas River below Silverton stream-flow gaging station (A-72; USGS gage site no. 09359020, see fig. 1). The data were collected at 15-minute intervals, and transmitted to the internet via satellite telemetry. The data from the continuous probe were semi-quantitative, and were not regularly checked against known turbidity standards. However, the turbidity data were critical in determining the timing of the time-series water-quality and toxicity samples. The monitor probe and internet hookup were installed September 25, 2001, and removed July 23, 2002 .

\section{Timing of Sampling}

In addition to reviewing the data from the continuous monitor probe, we looked at historical climate data and stream-flow hydrographs. Prior to the field effort, historical stream-flow discharge at the A-72 gage and air temperature data from the South Mineral Creek weather station were compiled to estimate the timing of the spring thaw. Over the past 9 years, the average date of the beginning of the spring thaw has been April 3. This analysis helped to forecast the event and to explain the hydrologic processes contributing to it. Data from the continuous monitor probe were inspected daily throughout March to observe patterns in discharge and turbidity.

The winter of 2001-2002 produced below 50 percent of normal snowfall resulting in an early and below-normal snowmelt runoff. Local weather for the Red Mountain Pass and Molas Pass weather stations was monitored for warming trends via internet. Between March 1 and March 27, 2002, turbidity began to increase while discharge and specific conductance were relatively stable. Sampling began on March 27, soon after the 4-person sampling team arrived in Silverton, and ended three days later on March 30 when rising discharge made the river difficult to wade. The increased levels of turbidity continued until about April 5.

The spring thaw is characterized by changes in discharge, turbidity, and specific conductance. Between March 27 and April 3, 2002, discharge had a strongly diurnal rising trend. The sampling timeframe brackets the transition between concentrated winter base flow and the higherdischarge, more dilute spring runoff. Figure 2 shows that the sampling period for this study did occur during the rising limb of the discharge curve, and that water-quality samples we collected are representative of spring-thaw conditions. 


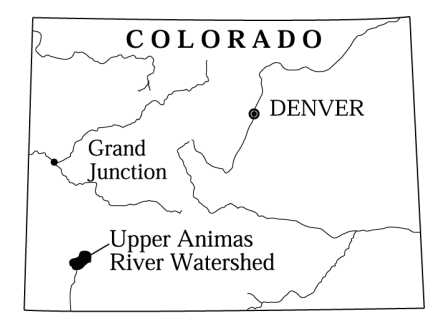

LOCATION MAP

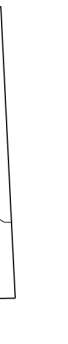

\section{EXPLANATION}

$\Delta$ Stream-flow gaging station and surface-water sampling site

4 Mines, prospect pits, or mining-related features

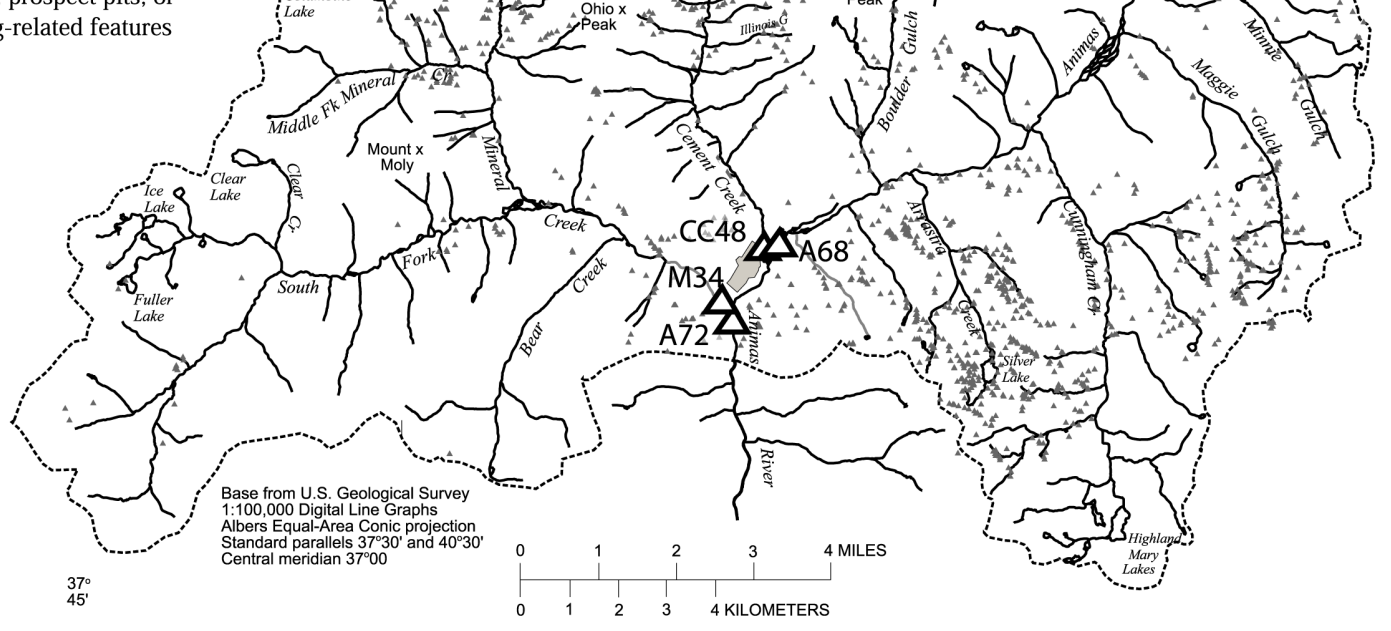

Figure 1. Map of the upper Animas River watershed, showing localities of mines and prospects (from USGS topographic maps), the localities of stream sampling and gaging sites, and index map showing location of the upper Animas River watershed in Colorado.

\section{Methods}

\section{Water Quality}

Sample Collection

A total of thirty water quality samples were collected from the Animas River and its tributaries near Silverton, Colorado during a 4-day period of high turbidity in which discharge increased at the A-72 gage from 70 to 140 cubic feet per second $\left(\mathrm{ft}^{3} / \mathrm{s}\right)$ and turbidity ranged from approximately 40 to 160 normal turbidity units (NTU). Twenty-one of the water-quality samples were collected near the A-72 gage below Silverton (fig 1). These time-series samples were collected in a wide, relatively shallow reach just upstream from the gage. Samples were collected from noon on March 27 until 6:00 PM on March 30. Samples were generally collected at 6 AM, 12 noon, 3 PM, 6 PM, 9 PM and 12 midnight. In addition, daily samples were collected near the gages on the three major upstream tributaries (fig 1) -Mineral Creek (M-34; gage site 09359010), Cement Creek (C48; gage site 09358550), and the upper Animas River near Silverton (A68; gage site 09358000). 


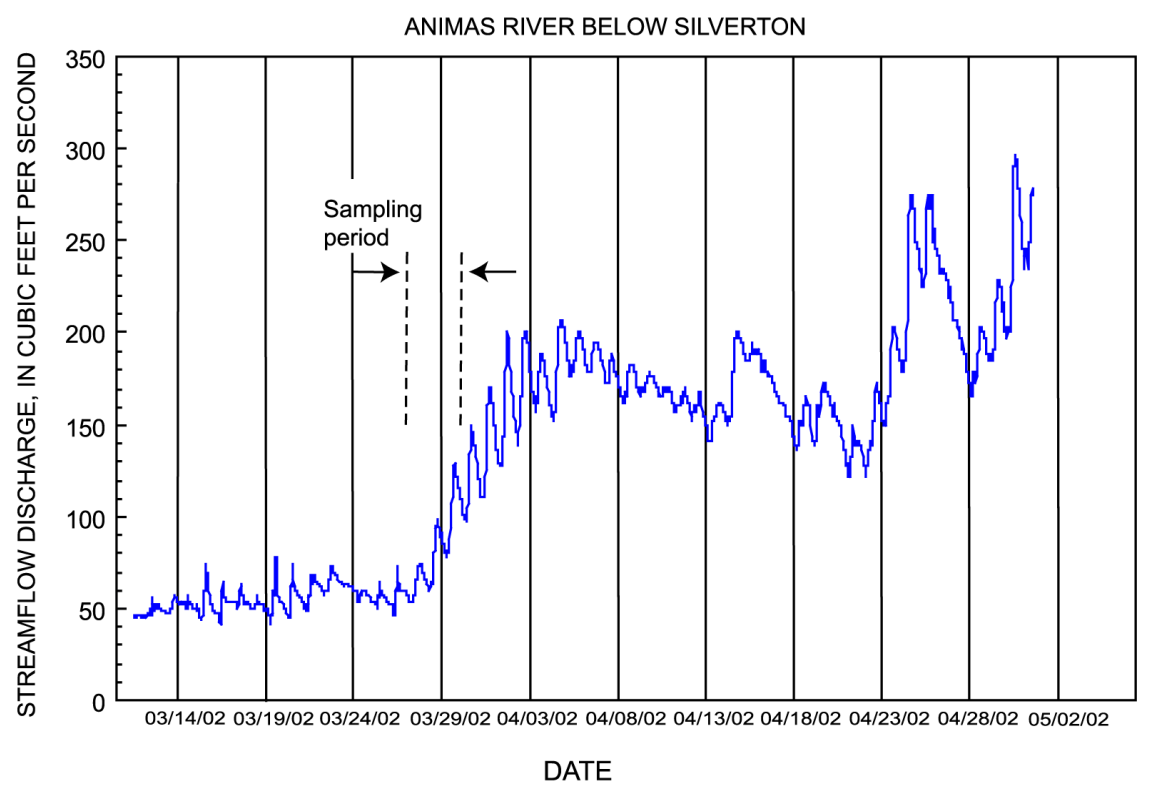

Figure 2. Graph showing discharge of Animas River from continuous water-quality monitor at A72 gage on Animas River below Silverton, Colorado, early March through early May 2002. The sampling period from March 27-30 is shown on the rising limb of the spring thaw.

Each flow-weighted composite sample was collected with a DH-81 wading sampler (Shelton, 1994) using the equal width integrated (EWI) approach described by Edwards and Glysson (1988). Field parameters including $\mathrm{pH}$, water temperature, specific conductance, and dissolved oxygen were measured onsite from a container of composite water. The $\mathrm{pH}$, temperature, and specific conductance values are in tables A1 and A2; dissolved oxygen readings were uncalibrated and incomplete, and are not presented. Samples were immediately transported to a refrigerator in a motel room in Silverton and acidified with ultrapure nitric acid usually within 12 hours of collection. An aliquot of each sample was filtered using a 0.45 -micron syringe-mounted filter and acidified with ultrapure hydrochloric acid for analysis of ferrous iron. A separate aliquot was filtered using a 0.45 -micron syringe-mounted filter and acidified with ultrapure nitric acid for analysis of dissolved iron $\left(\mathrm{Fe}^{+2}\right.$ and $\left.\mathrm{Fe}^{+3}\right)$.

Four duplicate samples were collected-(1) at site A-72 (A-72 119, duplicate of A-72 118), (2) at the Mineral Creek site (MC-104, duplicate of MC-103), (3) at the Cement Creek site (CC103, duplicate of CC-102), and (4) at the upper Animas River site (UA-104, duplicate of UA103). We also collected four field blanks by processing de-ionized laboratory water in the motel room.

Five suspended-sediment samples were collected at the A-72 site, one on March 27 (2 PM), one on March 28 (12 PM), two on March 29 (12 PM and 8:40 PM), and one on March 30 (6 PM). These samples were collected by filtering 6 liters of EWI stream water through a 142-millimeter diameter 0.7 micron filter in a pressurized stainless-steel filter apparatus.

\section{Water-Chemistry Analysis}

The unfiltered, acidified water samples were analyzed by ICP-AES (Briggs and Fey, 1996) and by inductively coupled plasma-mass spectroscopy (ICP-MS; Lamothe and others, 1999) for 26 elements and sulfate. Data are in tables A3-A4. Samples labeled A-72 100-123 are from A-72 gage site on the Animas River. Samples labeled CC 101-104 are from Cement Creek at Memorial Park in Silverton, about 0.2 mi below the C48 gage. Samples labeled MC 101-104 are from 
Mineral Creek just above its confluence with the Animas River, at gage M34. Samples labeled UA 101-104 are from the Animas River above Cement Creek, at the A68 gage. Filtered, unacidified water samples were analyzed for the anions fluoride, chloride, and nitrate, by ion chromatography (d'Angelo and Ficklin, 1996). These data are in table A1-A2. Quality control data from the field duplicates, field blanks, and analytical standards are in table A5.

Hydrochloric acid-filtered samples were measured for ferrous iron by spectrophotometer for only the samples from the A-72 site using the phenanthroline method (Hach Company, 1997).

The ferrous iron results are in table A1. Nitric acid-preserved filtered samples were analyzed for both forms of iron by ICP-AES; these results are also in table A1.

The suspended-sediment samples were analyzed by X-ray diffraction for mineralogy.

\section{Aquatic Toxicity Sample Collection}

A total of six water samples were collected at the A-72 site before, during, and after the spring thaw between March 22 and May 6, 2002 for toxicity testing. Unfiltered samples (10-20 L) were placed on ice and shipped on ice to the U.S. Geological Survey Columbia Environmental Research Center (CERC) in Missouri by overnight courier. Water samples were stored at $4{ }^{\circ} \mathrm{C}$ until used in toxicity tests. Two samples were used for each test: water for Test \#1 was collected on March 22 and March 27; water for Test \#2 was collected on March 28 and March 29; and water for Test \#3 was conducted on May 1 and May 6.

\section{Toxicity Tests}

Seven-day toxicity tests were conducted with the amphipod, Hyalella azteca, and the fathead minnow, Pimephales promelas (U.S. Environmental Protection Agency, 1994). Amphipod tests were started with juveniles (7- to 14-days old) and minnow tests were started with newly-hatched larvae (less than 48-hr old). The primary toxicity endpoint for both species was survival. Both species were exposed to undiluted (100 percent) stream water and a series of three dilutions (50 percent, 25 percent, and 12.5 percent). Stream water from the A-72 site was diluted with reconstituted water formulated to approximate the ionic composition of Animas River water during early snowmelt period ('Animas Hard' reconstituted water, or ARW; alkalinity $=9 \mathrm{mg} / \mathrm{L}$ as $\mathrm{CaCO}_{3}$, hardness $240 \mathrm{mg} / \mathrm{L}$, sulfate $213 \mathrm{mg} / \mathrm{L}$; Besser and others, 2001). Two sets of controls were used, one using ARW and another using CERC well water, diluted to equivalent hardness (diluted well water, DWW). Exposure water was replaced daily.

Toxicity data were rank-transformed and analyzed by analysis of variance. Comparisons between A-72 stream water (and dilutions) and controls (ARW) were made by Dunnett's onetailed test. Statements of statistical significance refer to $p \leq 0.05$.

\section{Water-Quality Results}

Discharge and turbidity at the A-72 gage site are related (fig 3) and both variables exhibit diurnal peaks. Daily maximum discharge and turbidity values occurred around 9 PM, and daily minimum values occurred around $9 \mathrm{am}$. Melting of snow during the daylight hours in the upper tributary basins provides increased water to the Animas River at A-72, with a lag time offsetting the integrated peak discharge. Over the duration of the sampling period, the difference between the low and high discharges also increased. On March 27, the flow ranged from 53 to 74 cubic feet per second $\left(\mathrm{ft}^{3} / \mathrm{s}\right)$, a variation of $21 \mathrm{ft}^{3} / \mathrm{s}$, or 28 percent. On March 29, the discharge ranged from 78 to $130 \mathrm{ft}^{3} / \mathrm{s}$, a variation of $52 \mathrm{ft}^{3} / \mathrm{s}$, or 40 percent. The diurnal rise in stream discharge is due to both an increase in stream velocity and cross-sectional area. This increase in channel size and water velocity (stream energy) results in a greater amount of suspended material, producing a corresponding increase in turbidity. 


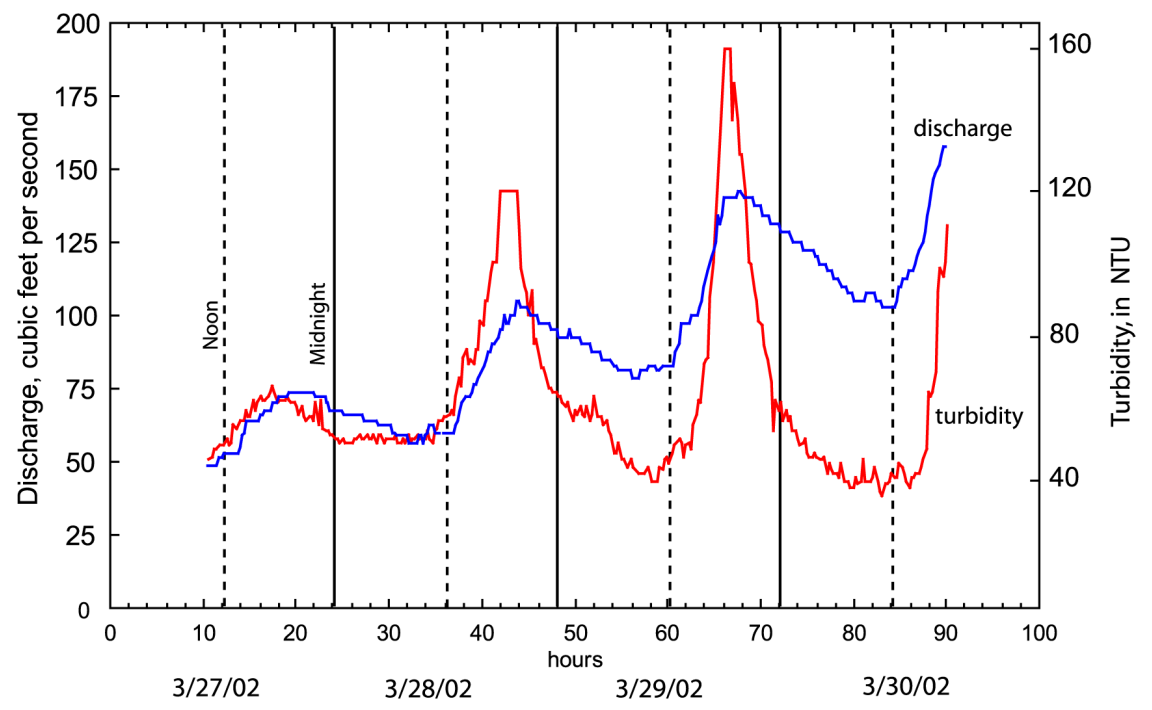

Figure 3. Graph showing the diurnal variations in and relation between discharge in $\mathrm{ft}^{3} / \mathrm{s}$ and turbidity in NTU versus time over the sampling period March 27-30, 2002. Turbidity values are semi-quantitative and subject to revision.

Some chemical constituents showed an increase in concentration with a diurnal response over the sampling period, some showed a decrease in concentration, also with a diurnal response, and some showed a diurnal response with small or no change in concentrations. Figure 4 shows the concentration curves of total calcium and strontium. The presence of these constituents in the water is the result of weathering of rock-forming minerals such as feldspars in the watershed. They show a noticeable decreasing concentration trend owing to dilution from the increased

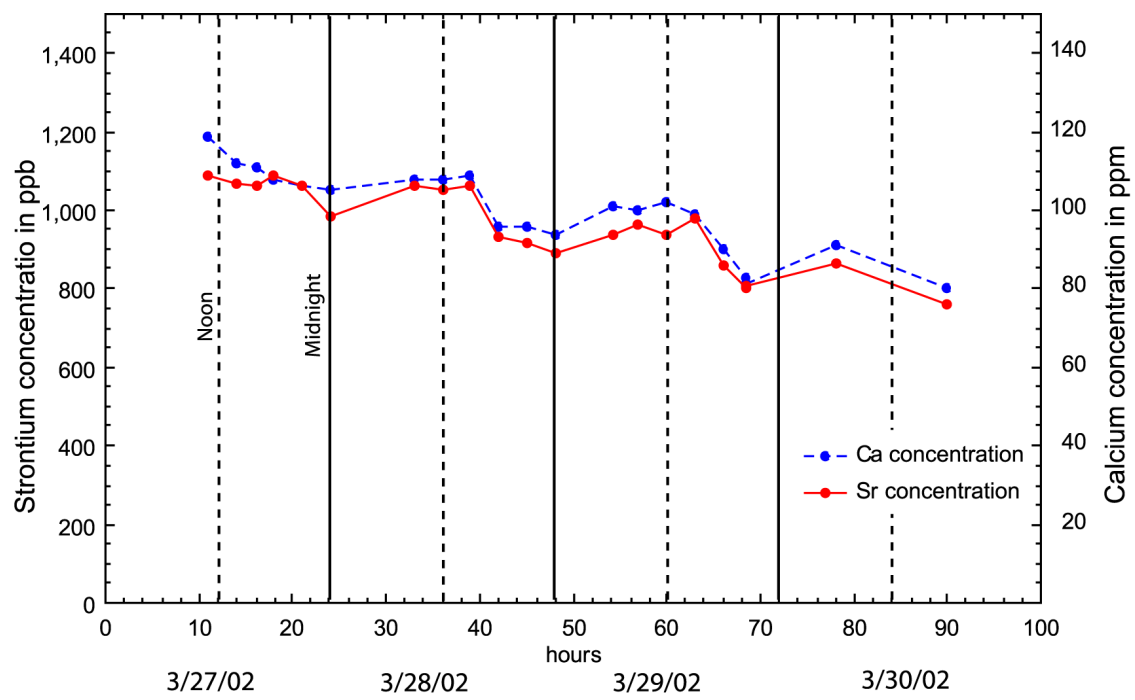

Figure 4. Graph showing total calcium and strontium concentrations for March 27-30, 2002 at the A-72 gage, Animas River below Silverton. The concentrations of both constituents decrease with time due to dilution by snowmelt, superposed by diurnal fluctuations. 
snowmelt discharge. Calcium and strontium concentrations also exhibit minimum and maximum concentrations; the maximum concentration roughly corresponding to the minimum discharge values, and the minimum concentrations corresponding to maximum discharge values. Calcium is the dominant cation in these waters.

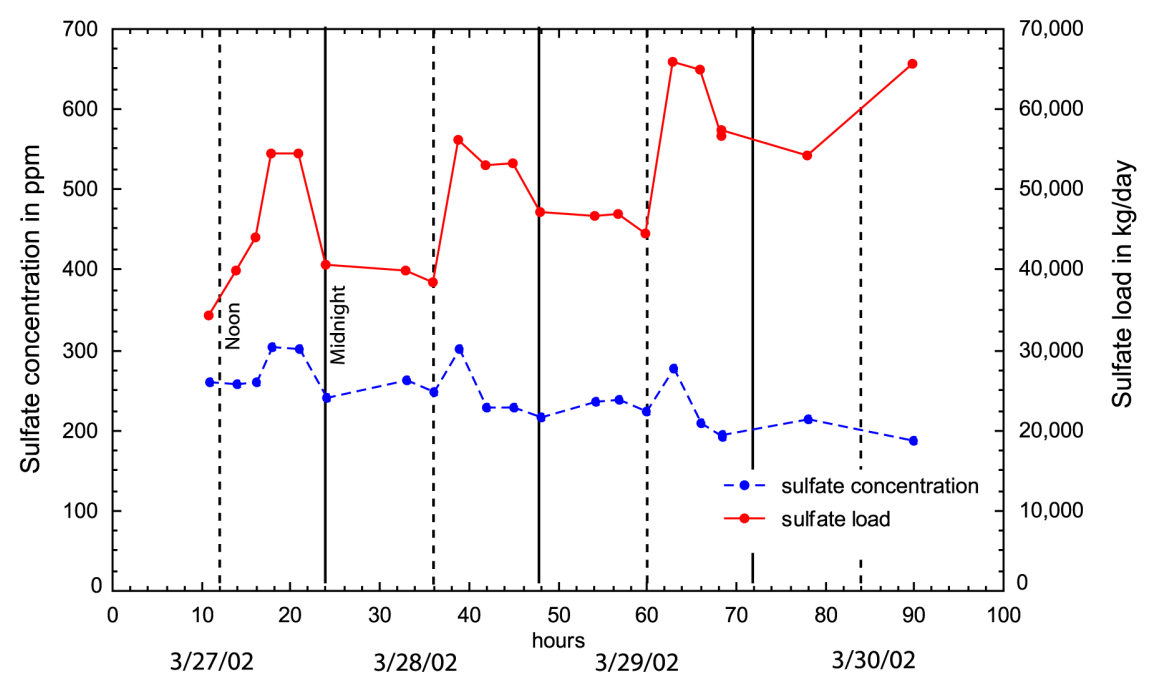

Figure 5. Graph showing total sulfate concentration and load for March 27-30, 2002 at the A-72 gage, Animas River below Silverton. Sulfate concentration shows a decreasing trend over time due to dilution by snowmelt, superposed by diurnal fluctuations.

Sulfate, the dominant anion, whose concentration through time is shown in figure 5, also exhibits a decreasing trend with diurnal peaks. The general decrease in sulfate concentration is due to dilution by snowmelt. The sulfate load, however, that is the concentration multiplied by the discharge, experiences a generally increasing trend.

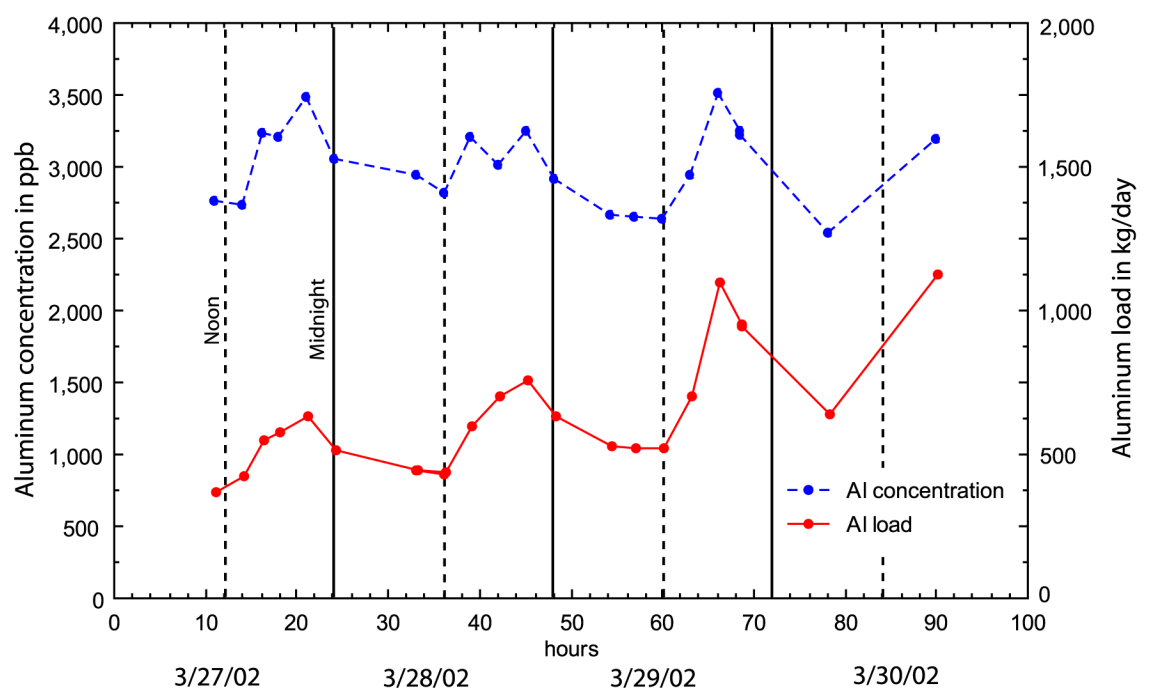

Figure 6. Graph showing total aluminum concentration and load for March 27-30, 2002 at the A72 gage, Animas River below Silverton. Aluminum concentrations do not increase or decrease with time but may show a slight diurnal pattern. 
The aluminum concentrations (fig 6) vary between 2,500 and 3,500 parts per billion (ppb). There appears to be some diurnal fluctuation in aluminum concentrations, but there is no clear trend.

Silicon concentrations (fig 7) show little variation over the sampling period. There is no clear diurnal response; however the silicon load increases over the sampling period due to the sharp increase in discharge.

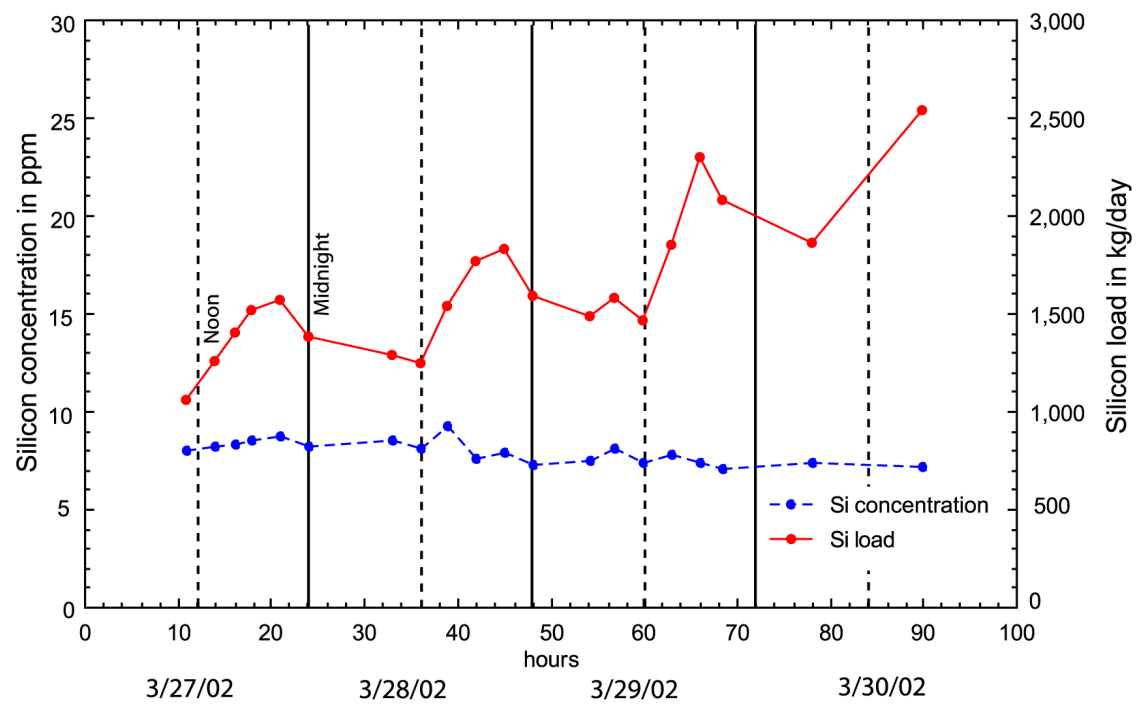

Figure 7. Graph showing total silicon concentration and load for March 27-30, 2002 at the A-72 gage, Animas River below Silverton. Silicon concentration shows little variation over time, with no obvious diurnal pattern.

Iron concentrations in unfiltered samples (total-recoverable iron) show a strong diurnal response (fig. 8, upper line). On March 28 and 29 a maximum concentration occurred about 9 PM. This maximum concentration was 2.5 times greater than the minimum concentrations, which occur at about $11 \mathrm{AM}$ or noon. The maximum and minimum values relate strongly to both discharge and turbidity. The concentration curves for both dissolved iron and ferrous iron (filtered at 0.45 microns) are also shown on figure 9 . The two curves match each other closely, indicating that the dissolved iron is present mostly as ferrous iron. The dissolved and ferrous iron concentrations range from 10 to 60 percent of the total-recoverable iron concentrations. The lowest ratios occur when the total-recoverable iron concentrations peak. Since this is when the turbidity and discharge are greatest, it is evident that at peak discharges, the majority of iron is transported as suspended material, and this material is responsible for the turbidity. X-ray diffraction of the suspended sediment material revealed that it is mostly amorphous colloidal material, with some detrital quartz and possibly some feldspar.

The response of dissolved (presumably mostly ferrous) iron concentrations in 0.45 -micronfiltered water shows an inverse response to turbidity and the total-iron concentrations (fig. 8). The ferrous iron concentrations peak at around noon and reach minimum values at around 9 PM. There are several mechanisms that may account for this relation. One explanation involves photoreduction of iron, and turbidity. More photoreduction of ferric iron from colloidal material to dissolved ferrous iron would occur during peak daylight hours, and when water is clearer. The largest dissolved ferrous iron concentrations occur at around noon, just before the turbidity begins 


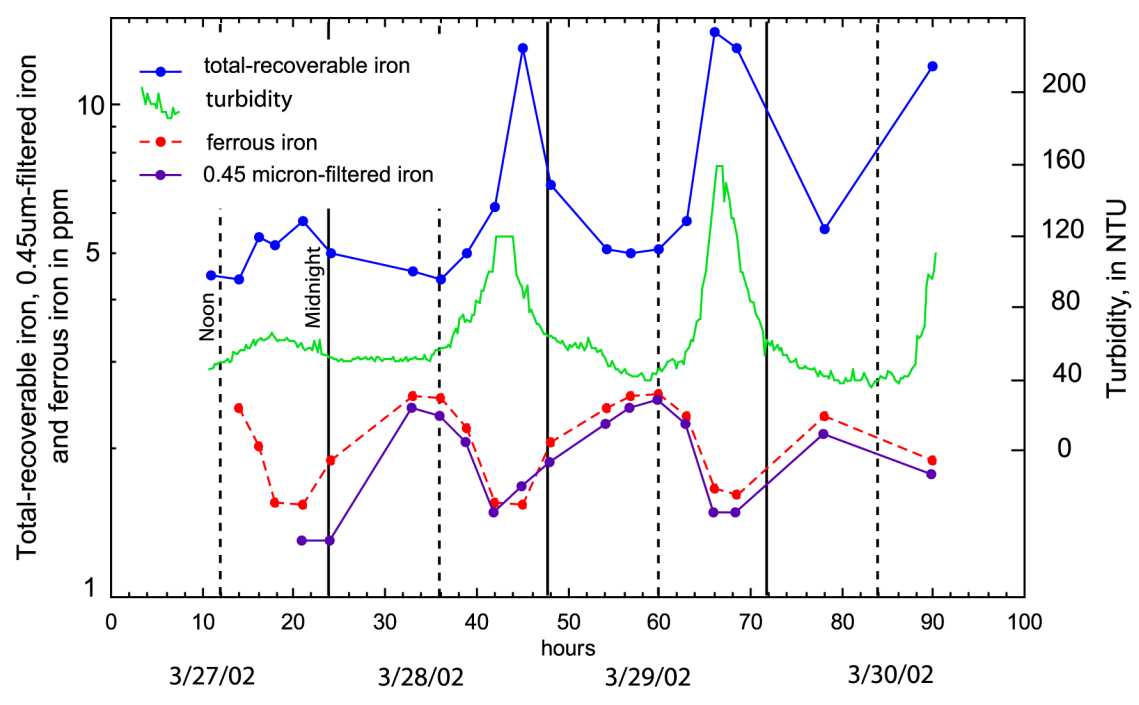

Figure 8. Graph showing turbidity in NTU, total-recoverable iron concentrations, 0.45 micronfiltered ferrous iron, and .045 micron-filtered ferrous plus ferric iron for March 27-30, 2002 at the A-72 gage, Animas River below Silverton. Iron concentrations are positively related with discharge and turbidity. The dissolved iron concentrations are inversely related to the totalrecoverable-iron and turbidity trends. Ferrous iron concentrations and ferrous plus ferric iron concentrations nearly match, indicating that the dissolved iron is predominantly ferrous. The ferrous iron concentration highs occur near noon on each day, indicating that photoreduction of ferric iron may be taking place. Turbidity values are semi-quantitative and subject to revision.

to rise (fig 8). The increase in turbidity would block sunlight from reaching the full depth of the water, reducing the amount of material exposed to photoreduction. Another explanation could be that increased discharge results in dilution of the dissolved iron.

A third possibility is that the increased turbidity of samples collected during the peak discharges causes plugging of the 0.45 - micron filters. If the dissolved iron is not truly dissolved, but present as material smaller than 0.45 microns, then plugging of the filter would prevent some of that material from being analyzed. However, the dissolved iron concentrations dip the same amount on the first day of the sampling period, when the turbidity and total-iron concentrations rise by only a small amount, suggesting that filter plugging is not the main factor. It is not clear which one or combination of factors is responsible for the relation between the dissolved iron and the total-recoverable iron.

The overall concentration trend of dissolved iron did not increase over the 3-day sampling period. However, the total-recoverable-iron load increased considerably, from $640 \mathrm{~kg} /$ day to over $4,000 \mathrm{~kg} /$ day (Fig. 9). Much of the iron load is present as colloidal material (Fig. 8); some of this colloidal iron fills in the interstitial space in the streambed, introducing other metals (see below) into that environment. These introduced metals can affect benthic invertebrate life (Fey and others, 2002).

Both copper (fig 10) and lead concentrations (fig 11) increase in response to diurnal changes in discharge. These concentrations are also related to total-recoverable iron concentrations. Copper and lead derive from the weathering of sulfide minerals in the watershed. Between stream $\mathrm{pH}$ of 5 to 6, these metals are largely sorbed to iron oxyhydroxides (Smith, 1999) that settle along stream banks and on streambed bottoms during low flow. The increases in copper and lead concentrations in unfiltered samples through time result from the increase in discharge, which mobilizes the bed sediment. 


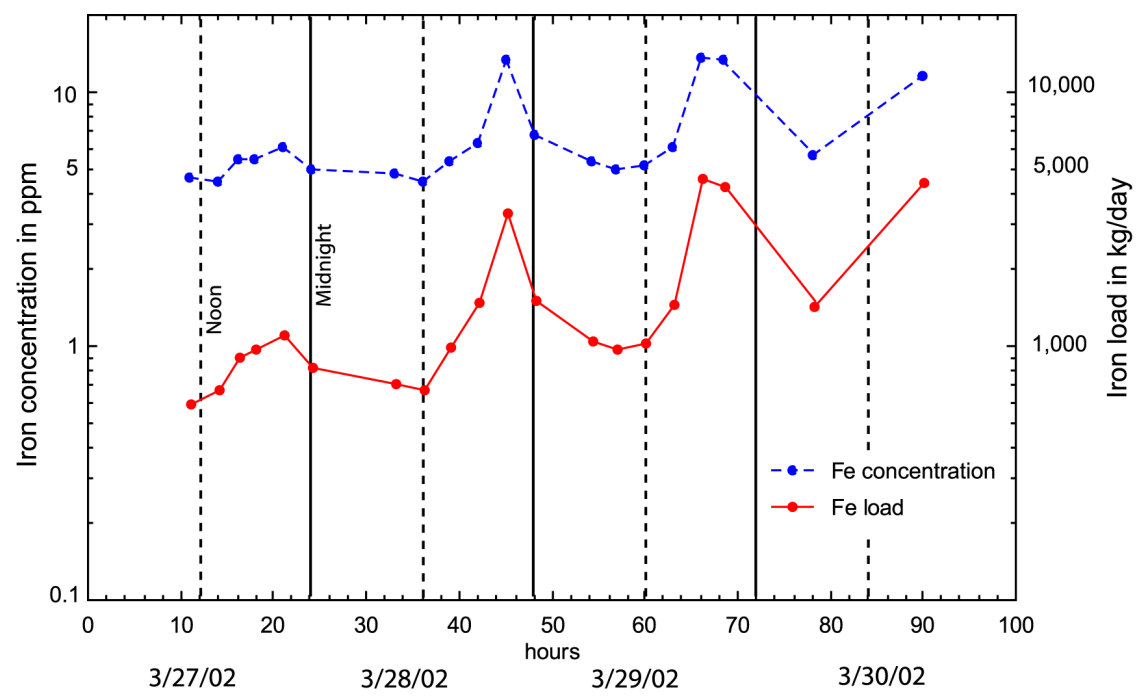

Figure 9. Graph showing total-recoverable iron concentration and load for March 27-30, 2002 at the A-72 gage, Animas River below Silverton.

Zinc concentrations are greater than either copper or lead concentrations (fig. 12). Zinc concentrations also exhibit a slight increasing trend, but do not show a distinct diurnal relation with iron or turbidity. Zinc is less likely to sorb to iron colloids under the ambient $\mathrm{pH}$ conditions (Smith, 1999) and so zinc concentrations do not correlate total-iron concentrations. Zinc is likely to be present as a dissolved species and not as a sorbed constituent.

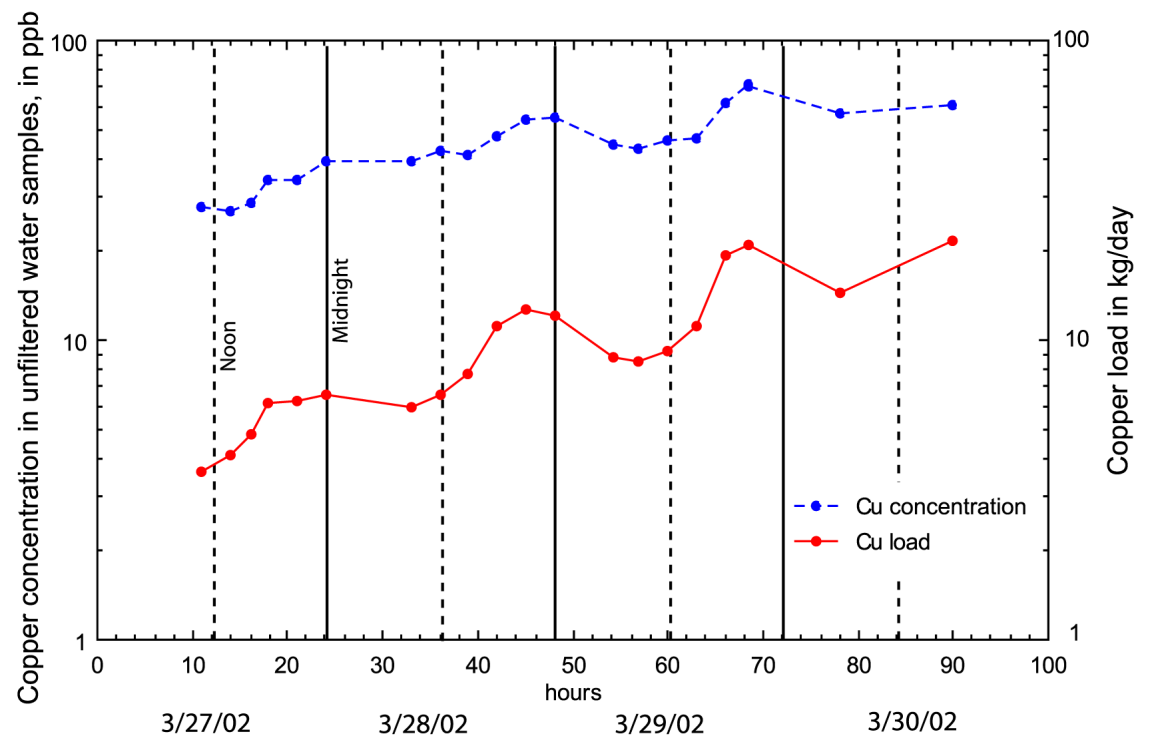

Figure 10. Graph showing total copper concentration and load for March 27-30, 2002 at the A-72 gage, Animas River below Silverton. Copper concentrations are positively related with iron concentrations, suggesting copper is sorbed to solid-phase iron material. 


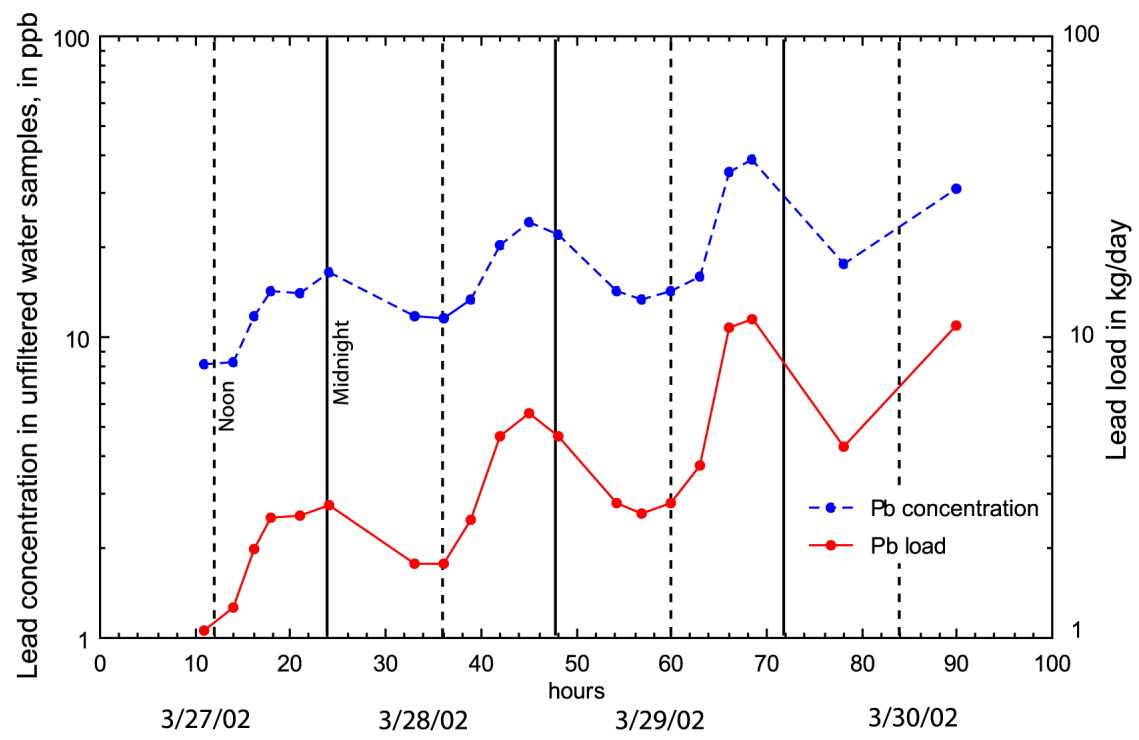

Figure 11. Graph showing total lead concentration and load for March 27-30, 2002 at the A-72 gage, Animas River below Silverton. Lead concentrations are positively related with iron concentrations, suggesting lead is sorbed to solid-phase iron material.

Figure 12 also shows the zinc load increased during the sampling period. Despite a relatively constant concentration, the load increases as a result of the increasing discharge. Copper and lead loads increased more than zinc loads, because these concentrations also increased.

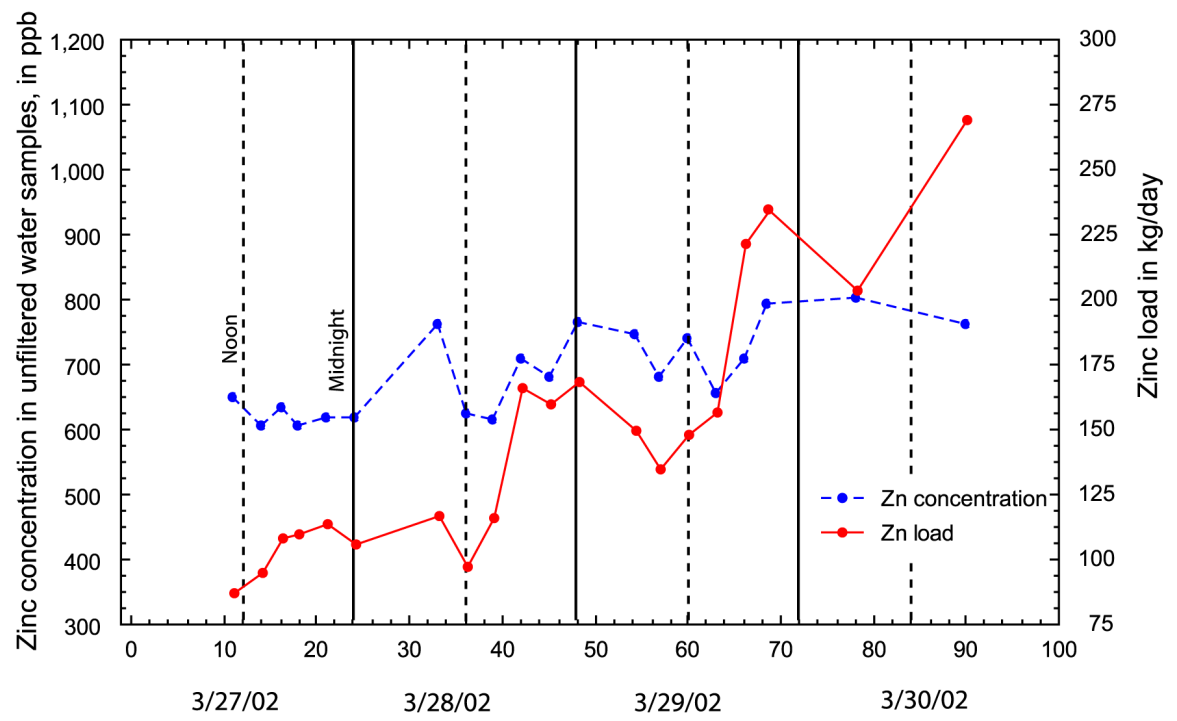

Figure 12. Graph showing total zinc concentration and load for March 27-30, 2002 at the A-72 gage, Animas River below Silverton. Variations in zinc are unrelated to those for turbidity or iron. At the $\mathrm{pH}$ of the sampled waters, zinc is not sorbed to colloidal iron material. Zinc load increase over time following the trend of diurnal discharge.

Tables A2 and A4 present data for water samples collected from the Cement Creek, Mineral Creek, and upper Animas River sites. Concentration difference between these sites and the Animas A-72 site demonstrate the geochemical differences between the subbasins. Aluminum 
concentrations were greatest in Cement Creek, probably a result of the weathering of clay-rich altered rock in that basin. The sulfate content of Cement Creek was greater than the other sites, probably due to exposures of acid-sulfate altered rock. Calcium, strontium, and iron concentrations were also greatest in Cement Creek, and the $\mathrm{pH}$ is the lowest of the three major tributaries. Mineral Creek had the highest concentrations of copper. The upper Animas River generally had the lowest concentrations of most other constituents, except manganese. Manganese concentrations and $\mathrm{pH}$ were highest in the upper Animas River.

\section{Aquatic Toxicity Results}

Amphipod toxicity tests did not show strong differences in toxicity among the three sampling periods (Figure 13). Undiluted water from the A-72 site caused nearly complete mortality of amphipods in all three tests. The high survival of amphipods in the 50 percent dilution in Test \#1 indicated that toxicity of stream water at the A-72 site during the pre-snowmelt period was less than that observed during the corresponding period in April 1999 (Besser and others, 2001). Toxicity of stream water to amphipods increased somewhat during Test \#2, as evidenced by significant toxic effects in the 50 percent dilution. Results of Test \#3 were difficult to interpret, because deterioration of the reconstituted ARW water (about one month after preparation) led to poor survival in all dilutions. However, undiluted stream water remained highly toxic during this test, with amphipod survival similar to that in tests conducted during late summer conditions in 1998 (Besser and others, 2001).

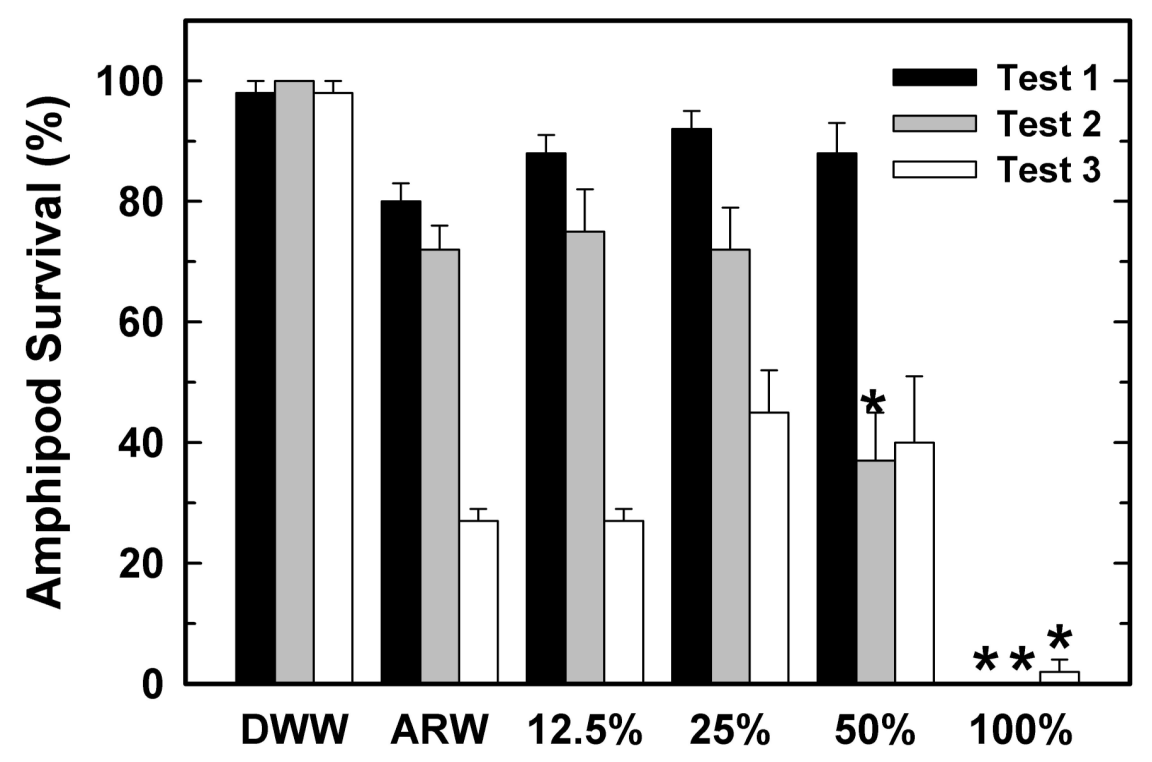

Figure 13. Graph showing toxicity of stream water from the Animas River (station A-72) and dilutions to amphipods (Hyalella azteca). Controls are DWW (diluted well water) and ARW (reconstituted Animas water). Asterisks indicate significant differences between stream water and controls (ARW). Undiluted (100\%) Animas sample water from all three sampling periods was toxic to Hyalella azteca. Toxicity observed in the $50 \%$ dilutions indicated greater toxicity in Test \#2 than in test \#1. Test \#3 results were affected by deteriorated control water (see text). 
Toxicity of stream water to fathead minnows showed a decreasing trend during the course of the study (fig. 14). Toxicity was greatest during pre-snowmelt conditions (Test \#1), when both undiluted stream water and the 50 percent dilution caused 100 percent mortality. Toxicity decreased slightly during early snowmelt (Test \#2), as indicated by partial survival in the 50 percent dilution, and no toxicity was observed during the late snowmelt period (Test \#3). For minnows, toxicity in the first two tests was similar to that observed in a previous pre-snowmelt period (April 1999), and the absence of toxicity during the late-snowmelt period was similar to results of previous tests with this species during late-summer low flow of August 1998 (Besser and others, 2001).

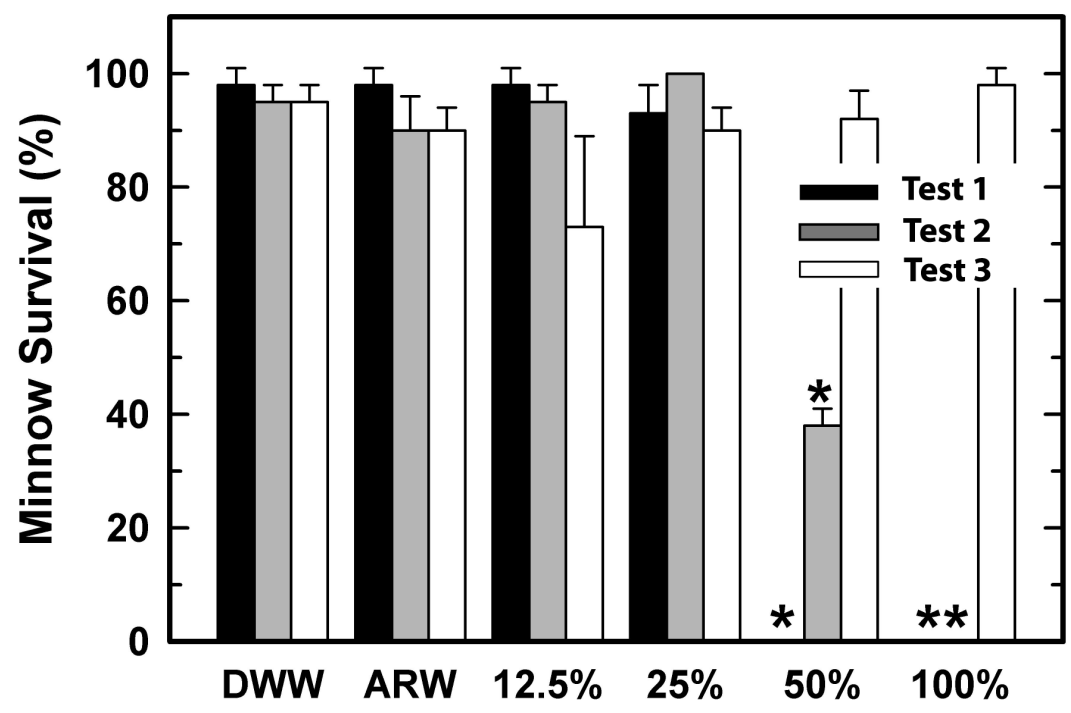

Figure 14. Graph showing toxicity of stream water from the Animas River (station A-72) and dilutions to fathead minnows (Pemephales promelas). Asterisks indicate significant differences between stream water and controls (ARW). Stream water was highly toxic to minnows in test \#1, but toxicity decreased slightly in test \#2, and was completely eliminated in test \#3.

\section{Summary}

Water quality, suspended sediment, and toxicity-testing water samples were collected from the Animas River near the A-72 gage station below Silverton, Colorado from March 27 to March 30, 2002. Discharge and specific conductance data from early March to early April 2002 and turbidity data from early March to early May 2002 characterizing the early spring thaw of the snow pack in the upper Animas River basin. Discharge was positively related to turbidity, and inversely related to specific conductance. Discharge, turbidity, and specific conductance showed strong diurnal patterns.

Analyses of unfiltered water samples at A-72 revealed that total-recoverable iron concentrations were positively related to turbidity and strongly diurnal. X-ray diffraction analysis indicated that suspended sediment is mostly amorphous, colloidal material. Total-recoverable iron concentrations increased three-fold and the total-recoverable iron load increased by nearly seven- 
fold over the sampling period. Copper and lead concentrations were related to total-recoverable iron concentrations, indicating these elements are likely sorbed to colloidal iron material. Zinc concentrations showed neither a strong diurnal pattern nor an increasing or decreasing concentration trend over time. Calcium, strontium, and sulfate concentrations showed diurnal and overall decreasing trends. Aluminum and silicon concentrations showed relatively little variation with some possible diurnal effects. The increase in discharge over the sampling period resulted in increasing loads for all constituents, including those whose concentrations decreased over time. Dissolved ferrous iron was inversely related to total-recoverable iron and turbidity. Maximum ferrous-iron concentrations occurred near noon each day, indicating photo reduction of ferric iron may be responsible. Alternative explanations for this occurrence include diurnal dilution and filter plugging.

Analyses of water samples from Cement Creek, Mineral Creek, and the upper Animas River demonstrated the difference in water chemistry between tributaries. Cement Creek had the greatest aluminum, sulfate, calcium, strontium, and iron concentrations and the lowest $\mathrm{pH}$. Mineral Creek had the greatest copper concentrations, and the upper Animas River had the greatest manganese concentrations and highest $\mathrm{pH}$.

Toxicity tests conducted with water from A-72 collected before, during, and after the spring thaw indicated little difference in toxicity between the pre-snowmelt and early snow-melt periods. Toxicity tests conducted using fathead minnows showed a decrease in toxicity over time, with no toxicity observed during the late snowmelt period. Results of the toxicity tests provide little evidence to support the hypothesis that turbid water from the early snowmelt or spring thaw period has greater toxicity than water from typical low-flow winter conditions.

\section{Acknowledgements}

Andy Gleason of the Silverton Avalanche group provided local weather information and snowmelt prediction. Robert McDougal provided valuable assistance during sample collection. We thank Monique Adams for the ICP-MS analyses, and Rhonda Driscoll for the X-ray diffraction analyses. Douglas Hardesty, Chris Ivey and James Kunz conducted the toxicity tests. We acknowledge Suzanne Paschke for her helpful review of this manuscript.

Funding for this study was partly provided by the Albuquerque District Office of the Army Corps of Engineers under contract number W81G6920955792. The USGS Central Region, Office of the Director, provided funding to purchase a continuous monitor probe at the Animas River below Silverton (A-72) stream-flow gaging station. 


\section{References}

Besser, J.M., and Leib, K.J., 1999, Modeling frequency of occurrence of toxic concentrations of zinc and copper in the upper Animas River, in U.S. Geological Survey Toxic Substance Hydrology Program, Proceedings of the technical meeting, Charleston, South Carolina, March 8-12, 1999--Volume 1-Contamination from Hardrock mining: U.S. Geological Survey Water Resources Investigations Report 99-4018A, p. 75-81.

Besser, J.M., Allert, A.L., Hardesty, D., Ingersoll, C.G., May, T.W., and Wang, N., 2001, Evaluation of metal toxicity in streams of the upper Animas River watershed, Colorado: Biological Science Report, BSR-2001-01. U.S. Geological Survey, Columbia Environmental Research Center, Columbia, Missouri.

Briggs, P.H., and Fey, D.L, 1996. Twenty-four elements in natural and acid mine waters by inductively coupled plasma-atomic emission spectrometry, in Arbogast, B.F., ed., Analytical methods manual for the Mineral Resources Program, U.S. Geological Survey Open-File Report 96-525, p. 95-101.

d'Angelo, W.M., and Ficklin, W.H., 1996, Fluoride, chloride, nitrate, and sulfate in aqueous solution by chemically suppressed ion chromatography, in Arbogast, B.F., ed., Analytical methods manual for the Mineral Resources Program, U.S. Geological Survey Open-File Report 96-525, p. 63-67.

Edwards, T.K., and Glysson, G.D., 1988, Field methods for measurement of fluvial sediment: U.S. Geological Survey Open-File Report 86-531, 118 p.

Fey, D.L., Church, S.E., Unruh, D.M. and Bove, D.J., 2002, Water and Sediment Study of the Snake River Watershed, Colorado, Oct 9-12, 2001: U.S. Geological Survey Open-File Report 02-330, $41 \mathrm{p}$.

Hach Company, 1997, DR/2010 Spectrophotometer Procedures Manual: p. 327-330.

Horowitz, A.J., and Elrick, K.A., 1987, The relation of stream sediment surface area, grain size, and composition to trace-element chemistry: Applied Geochemistry, Vol. 2, p. 437-451.

Lamothe, P.J., Meier, A.L., and Wilson, S.A., 1999, The determination of forty four elements in aqueous samples by Inductively Coupled Plasma - Mass Spectrometry, U.S. Geological Survey Open File Report 99-151, 14 p.

Leib, K.J., Wright, W.G., and Mast, M.A., 1999, Using flood-analysis techniques to estimate dissolved- zinc concentrations: Tailings and Mine Waste '99: Netherlands, A.A. Balkema Publications, p. 633- 638.

Shelton, L.R., 1994, Field guide for collection and processing stream-water samples for the National Water-Quality Assessment Program: U.S. Geological Survey Open-File Report 94$455,42 \mathrm{p}$.

Smith, K.S., 1999, Metal sorption on mineral surfaces: an overview with examples relating to mineral deposits: in Plumlee and Logsdon, editors, Reviews in economic geology, volume 6a, The environmental geochemistry of mineral deposits, $\mathrm{p}$ 161-182. 


\section{References}

Continued

Sullivan, A.B., and Drever, J.I., 2001, Spatiotemporal variability in stream chemistry in a highelevation catchment affected by mine drainage: Journal of Hydrology, v. 252, p. 237-250.

USEPA, 1994, Short-term methods for estimating the chronic toxicity of effluents and receiving water to freshwater organisms (Third edition): EPA-600-4-91-002.

Wirt, L., Leib, K. J., and Mast, M. A., 2000, Chemical-constituent loads during thunderstorm runoff in a high-altitude alpine stream affected by acid drainage: ICARD 2000; Proceedings from the Fifth International Conference on Acid Rock Drainage, Vol. II, p. 1391-1401. 
Appendix 1. Date, time, discharge and field parameters for unfiltered samples,

ferrous iron and ferrous plus ferric iron for filtered samples, and anion concentrations for filtered waters

USGS gage station A-72 (site number 09359020) near Silverton, Colorado, March 27-30, 2002

U.S. Geological Survey Open-File Report 02-0488

by D.L. Fey, L. Wirt, J.M. Besser, and W.G. Wright

\begin{tabular}{|c|c|c|c|c|c|c|c|c|c|c|c|c|c|}
\hline Sample No. & date & time & $\begin{array}{c}\text { discharge } \\
\text { CFS }\end{array}$ & $\begin{array}{c}\text { specific } \\
\text { conductance } \\
\text { uS/cm }\end{array}$ & pH & $\begin{array}{l}\text { Temp } \\
\operatorname{deg} C\end{array}$ & $\begin{array}{c}\text { Hardness } \\
\mathrm{mg} / \mathrm{L} \mathrm{CaCO}_{3}\end{array}$ & $\begin{array}{c}\text { Alkalinity } \\
\mathrm{mg}^{\prime} \mathrm{L} \mathrm{CaCO}_{3}\end{array}$ & $\begin{array}{l}\mathrm{Fe}^{2+} \\
\mathrm{mg} / \mathrm{L}\end{array}$ & $\begin{array}{c}\mathrm{e}^{2+} \text { plu } \\
\mathrm{Fe}^{3+} \\
\mathrm{mg} / \mathrm{L}\end{array}$ & $\begin{array}{c}\mathrm{Cl}^{-} \\
\mathrm{mg} / \mathrm{L}\end{array}$ & $\begin{array}{c}\mathbf{F}^{-} \\
\mathrm{mg} / \mathrm{L} \\
\end{array}$ & $\begin{array}{l}\mathrm{NO3}^{-} \\
\mathrm{mg} / \mathrm{L}\end{array}$ \\
\hline A72-100 & $3 / 22 / 02$ & 0900 & 57 & 662 & 4.88 & 3.4 & -- & -- & -- & -- & -- & - & -- \\
\hline A72-101 & $3 / 27 / 02$ & 1100 & 54 & 638 & 5.50 & 4.3 & 4.90 & 4.00 & -- & -- & 1.2 & 1.0 & $<.08$ \\
\hline A72-102 & $3 / 27 / 02$ & 1400 & 63 & 615 & 5.50 & 6.9 & 1.20 & 1.00 & 2.42 & -- & 1.3 & 1.0 & 0.5 \\
\hline A72-103 & $3 / 27 / 02$ & 1615 & 69 & 628 & 5.12 & 6.1 & 0.97 & 0.80 & 2.03 & -- & 1.3 & 1.0 & 0.5 \\
\hline A72-104 & $3 / 27 / 02$ & 1800 & 73 & 612 & 5.17 & 4.1 & -- & -- & 1.56 & -- & 1.5 & 1.1 & 0.7 \\
\hline A72-105 & $3 / 27 / 02$ & 2100 & 74 & 599 & 5.36 & 2.7 & 0.12 & 0.10 & 1.54 & 0.43 & 1.2 & 1.1 & $<.08$ \\
\hline A72-106 & $3 / 28 / 02$ & 0010 & 69 & 589 & 5.50 & 1.8 & 0.24 & 0.20 & 1.90 & 1.20 & 1.3 & 1.6 & 0.4 \\
\hline A72-107 & $3 / 28 / 02$ & 0900 & 62 & 606 & 5.70 & 1.4 & 2.92 & 2.40 & 2.55 & 2.40 & 1.4 & 0.9 & 0.4 \\
\hline A72-108 & $3 / 28 / 02$ & 1200 & 63 & 599 & 5.57 & 6.0 & 0.12 & 0.10 & 2.54 & 2.30 & 1.7 & 1.1 & 0.5 \\
\hline A72-109 & $3 / 28 / 02$ & 1500 & 76 & 627 & 4.88 & 8.6 & 2.20 & 1.80 & 2.21 & 2.00 & 1.4 & 0.8 & $<.08$ \\
\hline A72-110 & $3 / 28 / 02$ & 1800 & 95 & 553 & 5.43 & 3.6 & 1.49 & 1.40 & 1.55 & 1.40 & 1.5 & 0.9 & 0.6 \\
\hline A72-111 & $3 / 28 / 02$ & 2100 & 95 & 548 & 5.23 & 2.2 & 2.44 & 2.00 & 1.54 & 1.60 & 1.9 & 1.6 & 0.7 \\
\hline A72-112 & $3 / 29 / 02$ & 0005 & 89 & 544 & 5.26 & 1.2 & 0.98 & 0.80 & 2.06 & 1.80 & 1.6 & 1.2 & 1.0 \\
\hline A72-113 & $3 / 29 / 02$ & 0610 & 80 & 568 & 5.67 & 0.1 & 3.90 & 3.20 & 2.43 & 2.20 & 1.7 & 1.1 & 0.5 \\
\hline A72-114 & $3 / 29 / 02$ & 0900 & 80 & 611 & 5.70 & 1.4 & 2.93 & 2.40 & 2.57 & 2.40 & 1.9 & 1.1 & 0.6 \\
\hline A72-115 & $3 / 29 / 02$ & 1200 & 81 & 564 & 5.05 & 7.4 & -- & -- & 2.59 & 2.50 & 1.6 & 1.1 & 0.8 \\
\hline A72-116 & $3 / 29 / 02$ & 1502 & 97 & 583 & 5.15 & 7.2 & 1.46 & 1.20 & 2.32 & 2.20 & 1.6 & 0.9 & 0.6 \\
\hline A72-117 & $3 / 29 / 02$ & 1805 & 127 & 521 & 5.38 & 3.6 & 1.70 & 1.40 & 1.66 & 1.40 & 1.6 & 0.8 & 0.8 \\
\hline A72-118 & $3 / 29 / 02$ & 2040 & 127 & 495 & 5.30 & 2.3 & 1.83 & 1.50 & 1.61 & 1.50 & 1.8 & 1.6 & 0.5 \\
\hline A72-119 & $3 / 29 / 02$ & 2040 & 127 & 495 & 5.30 & 2.3 & 1.46 & 1.20 & 1.47 & 1.40 & 1.8 & 1.0 & 0.8 \\
\hline A72-120 & $3 / 30 / 02$ & 0610 & 103 & 523 & 5.69 & 0.2 & 4.15 & 3.40 & 2.33 & 2.10 & 1.8 & 0.8 & 0.7 \\
\hline A72-121 & $3 / 30 / 02$ & 1800 & 145 & 482 & 5.43 & 4.4 & 0.49 & 0.40 & 1.90 & 1.70 & 1.6 & 0.8 & $<.08$ \\
\hline A72-122 & 5/1/02 & 1340 & 246 & 283 & 6.35 & 8.3 & 12.80 & 10.5 & 0.35 & -- & -- & -- & -- \\
\hline A72-123 & $5 / 6 / 02$ & 1440 & 270 & 255 & 6.02 & 11.5 & 14.02 & 11.5 & -- & -- & -- & -- & -- \\
\hline
\end{tabular}


Appendix 2. Date, time, field parameters for unfiltered samples, ferrous iron for filtered samples,

and anion concentrations for filtered waters at Cement Creek in Memorial Park (CC-48; 09358550),

Mineral Creek above Animas River (M-34; 09359010),

and upper Animas River (A-68 09358000), March 27-30, 2002

U.S. Geological Survey Open-File Report 02-0488

by D.L. Fey, L. Wirt, J.M. Besser, and W.G. Wright

specific

\begin{tabular}{|c|c|c|c|c|c|c|c|c|c|c|c|}
\hline Sample No. & date & time & $\begin{array}{c}\text { conductance } \\
\text { uS/cm }\end{array}$ & $\mathrm{pH}$ & $\begin{array}{c}T \\
\operatorname{deg} C\end{array}$ & $\begin{array}{c}\text { Hardness } \\
\mathrm{mg} / \mathrm{L} \mathrm{CaCO} \mathrm{CaCO}_{3}\end{array}$ & $\begin{array}{c}\text { Alkalinity } \\
\mathrm{mg}^{\prime} \mathrm{LaCO}_{3}\end{array}$ & $\begin{array}{c}\mathrm{Fe}^{2+} \\
\mathrm{mg} / \mathrm{L}\end{array}$ & $\begin{array}{c}\mathrm{Cl}^{-} \\
\mathrm{mg} / \mathrm{L}\end{array}$ & $\begin{array}{r}\mathbf{F}^{-} \\
\mathrm{mg} / \mathrm{L}\end{array}$ & $\begin{array}{l}\mathrm{NO3}^{-} \\
\mathrm{mg} / \mathrm{L}\end{array}$ \\
\hline CC-101 & $3 / 27 / 02$ & 1535 & 1032 & 3.88 & 8.8 & 0 & 0 & -- & 0.2 & 1.5 & 0.6 \\
\hline CC-102 & $3 / 28 / 02$ & 1430 & 961 & 3.80 & 9.8 & 0 & 0 & -- & 0.3 & 1.9 & $<.08$ \\
\hline CC-103 & $3 / 28 / 02$ & 1435 & 961 & 3.80 & 9.8 & 0 & 0 & -- & 0.5 & 1.5 & $<.08$ \\
\hline CC-104 & $3 / 29 / 02$ & 1740 & 787 & 3.79 & 6.3 & 0 & 0 & -- & 1.6 & 0.7 & 1.1 \\
\hline MC-101 & $3 / 27 / 02$ & 1500 & 648 & 5.12 & 6.1 & 0.61 & 1.50 & -- & 1.5 & 1.2 & 0.6 \\
\hline MC-102 & $3 / 28 / 02$ & 1415 & 635 & 4.25 & 5.2 & 0 & 0 & -- & 2.2 & 0.7 & 0.6 \\
\hline MC-103 & $3 / 29 / 02$ & 1410 & 560 & 4.45 & 5.5 & 0 & 0 & -- & 3.0 & 0.8 & $<.2$ \\
\hline MC-104 & $3 / 29 / 02$ & 1805 & 525 & 4.71 & 3.1 & 0.24 & 0.20 & -- & 2.5 & 0.6 & 0.6 \\
\hline UA-101 & $3 / 27 / 02$ & 1530 & 416 & 6.92 & 3.2 & 33 & 27 & -- & 1.2 & 0.7 & 0.5 \\
\hline UA-102 & $3 / 28 / 02$ & 1430 & 426 & 6.11 & 4.9 & 34 & 30 & -- & 1.4 & 0.6 & 0.7 \\
\hline UA-103 & $3 / 29 / 02$ & 1720 & 378 & 6.59 & 2.2 & 32 & 26 & -- & 1.4 & 0.6 & 1.6 \\
\hline UA-104 & $3 / 29 / 02$ & 1715 & 415 & 6.06 & 2.2 & 31 & 25 & -- & 1.4 & 0.8 & 1.3 \\
\hline
\end{tabular}


Appendix 3. Date, time, discharge, and major and trace element data for unfiltered water at USGS gage station A-72 (09359020) near Silverton, Colorado, March 27-30, 2002

U.S. Geological Survey Open-File Report 02-0488

by D.L. Fey, L. Wirt, J.M. Besser, and W.G. Wright

\begin{tabular}{|c|c|c|c|c|c|c|c|c|c|c|c|c|c|c|c|c|c|}
\hline Field No. & date & time & $\begin{array}{c}\text { discharge } \\
\text { CFS }\end{array}$ & $\begin{array}{l}\text { Al ug/L } \\
\text { ICP-MS }\end{array}$ & $\begin{array}{l}\text { As ug/L } \\
\text { ICP-MS }\end{array}$ & $\begin{array}{l}\text { Ba ug/L } \\
\text { ICP-MS }\end{array}$ & $\begin{array}{l}\text { Be ug/L } \\
\text { ICP-MS }\end{array}$ & $\begin{array}{l}\text { Ca mg/L } \\
\text { ICP-AES }\end{array}$ & $\begin{array}{l}\text { Cd ug/L } \\
\text { ICP-MS }\end{array}$ & $\begin{array}{l}\text { Co ug/L } \\
\text { ICP-MS }\end{array}$ & $\begin{array}{l}\text { Cu ug/L } \\
\text { ICP-MS }\end{array}$ & $\begin{array}{l}\text { Fe mg/L } \\
\text { ICP-AES }\end{array}$ & $\begin{array}{l}\mathrm{K} \mathrm{mg/L} \\
\text { ICP-MS }\end{array}$ & $\begin{array}{l}\text { La ug/L } \\
\text { ICP-MS }\end{array}$ & $\begin{array}{l}\text { Li ug/L } \\
\text { ICP-MS }\end{array}$ & $\begin{array}{l}\text { Mg mg/L } \\
\text { ICP-AES }\end{array}$ & $\begin{array}{l}\text { Mn ug/L } \\
\text { ICP-MS }\end{array}$ \\
\hline A72-101 & $3 / 27 / 02$ & 1100 & 54 & 2760 & 2.0 & 21.0 & 0.3 & 119 & 2.12 & 7.57 & 27.7 & 4.5 & 1.1 & 2.11 & 8.4 & 6.5 & 1630 \\
\hline A72-102 & $3 / 27 / 02$ & 1400 & 63 & 2730 & 2.0 & 21.6 & 0.3 & 112 & 2.01 & 8.02 & 26.8 & 4.4 & 1.1 & 2.22 & 8.6 & 6.6 & 1630 \\
\hline A72-103 & $3 / 27 / 02$ & 1615 & 69 & 3240 & 2.0 & 21.2 & 0.4 & 111 & 2.11 & 8.28 & 28.8 & 5.4 & 1.1 & 2.53 & 9.0 & 6.7 & 1910 \\
\hline A72-104 & $3 / 27 / 02$ & 1800 & 73 & 3210 & 2.0 & 23.3 & 0.3 & 108 & 2.15 & 7.79 & 34.5 & 5.2 & 1.2 & 2.14 & 8.8 & 6.2 & 2000 \\
\hline A72-105 & $3 / 27 / 02$ & 2100 & 74 & 3490 & 3.0 & 22.9 & 0.4 & 106 & 2.16 & 9.00 & 34.5 & 5.8 & 1.2 & 2.45 & 8.7 & 6.3 & 1880 \\
\hline A72-106 & $3 / 28 / 02$ & 0010 & 69 & 3060 & 2.0 & 22.3 & 0.3 & 105 & 2.27 & 7.89 & 39.3 & 5.0 & 1.1 & 2.38 & 8.2 & 6.0 & 1690 \\
\hline A72-107 & $3 / 28 / 02$ & 0900 & 62 & 2940 & 2.0 & 21.6 & 0.3 & 108 & 2.43 & 7.59 & 39.7 & 4.6 & 1.1 & 2.12 & 8.5 & 6.3 & 1750 \\
\hline A72-108 & $3 / 28 / 02$ & 1200 & 63 & 2820 & 2.0 & 22.1 & 0.3 & 108 & 2.24 & 8.41 & 43.0 & 4.4 & 1.0 & 2.18 & 8.1 & 6.2 & 1600 \\
\hline A72-109 & $3 / 28 / 02$ & 1500 & 76 & 3210 & 2.0 & 22.4 & 0.3 & 109 & 2.22 & 8.41 & 41.7 & 5.0 & 1.1 & 2.28 & 8.6 & 6.3 & 1940 \\
\hline A72-110 & 3/28/02 & 1800 & 95 & 3020 & 3.0 & 23.1 & 0.4 & 96 & 2.37 & 6.97 & 48.1 & 6.2 & 1.1 & 2.42 & 8.0 & 5.8 & 1830 \\
\hline A72-111 & $3 / 28 / 02$ & 2100 & 95 & 3250 & 4.1 & 25.2 & 0.4 & 96 & 2.46 & 7.55 & 54.9 & 13 & 1.3 & 2.48 & 8.2 & 5.7 & 1680 \\
\hline A72-112 & $3 / 29 / 02$ & 0005 & 89 & 2910 & 3.0 & 23.1 & 0.4 & 94 & 2.62 & 7.30 & 55.2 & 6.9 & 1.2 & 2.38 & 7.8 & 5.8 & 1650 \\
\hline A72-113 & 3/29/02 & 0610 & 80 & 2660 & 2.0 & 22.3 & 0.3 & 101 & 2.57 & 6.91 & 44.7 & 5.1 & 1.1 & 2.07 & 7.9 & 6.0 & 1660 \\
\hline A72-114 & 3/29/02 & 0900 & 80 & 2650 & 3.0 & 22.6 & 0.3 & 100 & 2.54 & 6.87 & 43.7 & 5.0 & 1.1 & 2.03 & 8.2 & 6.0 & 1590 \\
\hline A72-115 & 3/29/02 & 1200 & 81 & 2640 & 2.0 & 22.0 & 0.3 & 102 & 2.65 & 7.15 & 46.5 & 5.1 & 1.0 & 2.15 & 7.8 & 6.0 & 1640 \\
\hline A72-116 & 3/29/02 & 1502 & 97 & 2950 & 2.0 & 22.3 & 0.3 & 99 & 2.52 & 7.82 & 47.2 & 5.8 & 1.1 & 2.18 & 8.3 & 6.0 & 1950 \\
\hline A72-117 & 3/29/02 & 1805 & 127 & 3520 & 5.4 & 29.4 & 0.4 & 90 & 2.64 & 7.42 & 61.7 & 14 & 1.1 & 2.79 & 8.1 & 5.7 & 1860 \\
\hline A72-118 & 3/29/02 & 2040 & 127 & 3250 & 4.8 & 29.1 & 0.4 & 83 & 2.76 & 7.40 & 71.1 & 13 & 1.2 & 2.79 & 7.7 & 5.4 & 1650 \\
\hline A72-119 & 3/29/02 & 2040 & 127 & 3220 & 4.1 & 28.6 & 0.4 & 81 & 2.80 & 7.23 & 70.5 & 12 & 1.2 & 2.59 & 7.6 & 5.4 & 1650 \\
\hline A72-120 & 3/30/02 & 0610 & 103 & 2540 & 2.0 & 23.4 & 0.3 & 91 & 3.42 & 6.79 & 56.9 & 5.6 & 0.98 & 2.02 & 7.6 & 5.4 & 1690 \\
\hline A72-121 & $3 / 30 / 02$ & 1800 & 145 & 3190 & 4.0 & 29.8 & 0.4 & 80 & 3.28 & 7.00 & 61.3 & 12 & 1.0 & 2.52 & 7.6 & 5.2 & 1700 \\
\hline
\end{tabular}


Appendix 3. Date, time, discharge, and major and trace element data for unfiltered water at USGS gage station A-72 (09359020) near Silverton, Colorado, March 27-30, 2002

continued

U.S. Geological Survey Open-File Report 02-0488

by D.L. Fey, L. Wirt, J.M. Besser, and W.G. Wright

\begin{tabular}{|c|c|c|c|c|c|c|c|c|c|c|c|c|c|c|c|c|}
\hline Field No. & date & time & $\begin{array}{c}\text { discharge } \\
\text { CFS }\end{array}$ & $\begin{array}{l}\text { Mo ug/L } \\
\text { ICP-MS }\end{array}$ & $\begin{array}{l}\mathrm{Na} \mathrm{mg} / \mathrm{L} \\
\text { ICP-AES }\end{array}$ & $\begin{array}{l}\mathrm{Ni} \text { ug/L } \\
\text { ICP-MS }\end{array}$ & $\begin{array}{l}\mathrm{P} \mathrm{mg} / \mathrm{L} \\
\text { ICP-MS }\end{array}$ & $\begin{array}{l}\mathrm{Pb} \text { ug/L } \\
\text { ICP-MS }\end{array}$ & $\begin{array}{l}\text { Sc ug/L } \\
\text { ICP-MS }\end{array}$ & $\begin{array}{l}\text { Si mg/L } \\
\text { ICP-MS }\end{array}$ & $\begin{array}{l}\text { SO } 4 \mathrm{mg} / \mathrm{L} \\
\text { ICP-MS }\end{array}$ & $\begin{array}{l}\text { Sr ug/L } \\
\text { ICP-MS }\end{array}$ & $\begin{array}{l}\text { Ti ug/L } \\
\text { ICP-MS }\end{array}$ & $\begin{array}{l}\text { V ug/L } \\
\text { ICP-MS }\end{array}$ & $\begin{array}{l}\text { Y ug/L } \\
\text { ICP-MS }\end{array}$ & $\begin{array}{l}\text { Zn ug/L } \\
\text { ICP-MS }\end{array}$ \\
\hline A72-101 & $3 / 27 / 02$ & 1100 & 54 & 0.79 & 4.0 & 7.3 & 0.02 & 8.1 & 1.6 & 8.0 & 259 & 1090 & 3.6 & 0.9 & 5.7 & 649 \\
\hline A72-102 & $3 / 27 / 02$ & 1400 & 63 & 0.55 & 4.0 & 7.3 & 0.02 & 8.2 & 1.5 & 8.2 & 258 & 1070 & 4.0 & 0.9 & 5.9 & 606 \\
\hline A72-103 & $3 / 27 / 02$ & 1615 & 69 & 0.62 & 3.9 & 7.4 & 0.04 & 11.7 & 1.6 & 8.3 & 260 & 1060 & 5.0 & 1.3 & 6.3 & 633 \\
\hline A72-104 & $3 / 27 / 02$ & 1800 & 73 & 0.68 & 4.0 & 7.0 & 0.04 & 14.2 & 1.6 & 8.5 & 305 & 1090 & 5.3 & 1.4 & 5.4 & 607 \\
\hline A72-105 & $3 / 27 / 02$ & 2100 & 74 & 0.60 & 3.9 & 7.2 & 0.05 & 14.1 & 1.6 & 8.7 & 301 & 1060 & 4.6 & 1.6 & 6.1 & 620 \\
\hline A72-106 & $3 / 28 / 02$ & 0010 & 69 & 0.69 & 3.5 & 7.1 & 0.03 & 16.4 & 1.5 & 8.2 & 240 & 984 & 4.2 & 1.0 & 5.7 & 620 \\
\hline A72-107 & $3 / 28 / 02$ & 0900 & 62 & 0.96 & 4.2 & 7.3 & 0.02 & 11.7 & 1.6 & 8.5 & 262 & 1060 & 3.6 & 1.0 & 5.4 & 761 \\
\hline A72-108 & $3 / 28 / 02$ & 1200 & 63 & 0.84 & 3.6 & 69 & 0.02 & 11.6 & 1.4 & 8.1 & 249 & 1050 & 3.4 & 0.8 & 5.6 & 624 \\
\hline A72-109 & $3 / 28 / 02$ & 1500 & 76 & 0.51 & 4.0 & 7.5 & 0.03 & 13.4 & 1.5 & 8.3 & 302 & 1060 & 4.6 & 1.1 & 5.8 & 616 \\
\hline A72-110 & $3 / 28 / 02$ & 1800 & 95 & 0.96 & 3.8 & 6.8 & 0.05 & 20.2 & 1.6 & 7.6 & 228 & 934 & 4.7 & 1.6 & 5.3 & 708 \\
\hline A72-111 & $3 / 28 / 02$ & 2100 & 95 & 0.57 & 3.5 & 7.8 & 0.09 & 24.0 & 1.5 & 7.9 & 229 & 915 & 4.7 & 3.0 & 5.5 & 681 \\
\hline A72-112 & $3 / 29 / 02$ & 0005 & 89 & 0.53 & 3.8 & 6.4 & 0.04 & 21.8 & 1.4 & 7.3 & 217 & 893 & 3.9 & 1.4 & 5.4 & 767 \\
\hline A72-113 & $3 / 29 / 02$ & 0610 & 80 & 0.58 & 3.7 & 6.8 & 0.03 & 14.2 & 1.6 & 7.5 & 235 & 936 & 4.0 & 0.9 & 4.9 & 748 \\
\hline A72-114 & $3 / 29 / 02$ & 0900 & 80 & 2.47 & 3.8 & 6.2 & 0.03 & 13.4 & 1.4 & 8.1 & 239 & 964 & 3.3 & 0.9 & 4.9 & 682 \\
\hline A72-115 & 3/29/02 & 1200 & 81 & 0.68 & 3.8 & 6.7 & 0.03 & 14.2 & 1.5 & 7.4 & 224 & 938 & 3.9 & 0.9 & 5.1 & 742 \\
\hline A72-116 & $3 / 29 / 02$ & 1502 & 97 & 0.55 & 3.7 & 6.9 & 0.04 & 15.8 & 1.4 & 7.8 & 277 & 981 & 4.3 & 1.0 & 5.2 & 655 \\
\hline A72-117 & $3 / 29 / 02$ & 1805 & 127 & 0.87 & 3.6 & 6.7 & 0.10 & 35.1 & 1.7 & 7.4 & 209 & 861 & 7.6 & 3.3 & 5.5 & 710 \\
\hline A72-118 & $3 / 29 / 02$ & 2040 & 127 & 1.05 & 3.5 & 6.4 & 0.10 & 39.2 & 1.6 & 7.1 & 193 & 802 & 6.5 & 2.7 & 5.3 & 728 \\
\hline A72-119 & $3 / 29 / 02$ & 2040 & 127 & 0.67 & 3.4 & 6.2 & 0.10 & 34.4 & 1.6 & 7.1 & 195 & 807 & 5.6 & 2.5 & 5.3 & 795 \\
\hline A72-120 & $3 / 30 / 02$ & 0610 & 103 & 0.96 & 3.3 & 6.1 & 0.03 & 17.4 & 1.4 & 7.4 & 215 & 866 & 3.6 & 1.0 & 4.5 & 803 \\
\hline A72-121 & $3 / 30 / 02$ & 1800 & 145 & 0.75 & 3.0 & 5.7 & 0.10 & 31.3 & 1.5 & 7.2 & 186 & 762 & 5.4 & 2.6 & 4.8 & 761 \\
\hline
\end{tabular}


Appendix 4. Date, time, and major and trace element data for unfiltered water

at Cement Creek in Memorial Park (CC-48; 09358550),

Mineral Creek above Animas River (M-34; 09359010),

and upper Animas River (A-68 09358000), March 27-30, 2002

U.S. Geological Survey Open-File Report 02-0488

by D.L. Fey, L. Wirt, J.M. Besser, and W.G. Wright

Field No. date time Al ug/L As ug/L Ba ug/L Be ug/L Ca mg/L Cd ug/L Co ug/L Cu ug/L Fe mg/L K mg/L La ug/L Li ug/L Mg mg/L Mn ug/L ICP-MS ICP-MS ICP-MS ICP-MS ICP-AES ICP-MS ICP-MS ICP-MS ICP-AES ICP-MS ICP-MS ICP-MS ICP-AES ICP-MS

\begin{tabular}{|c|c|c|c|c|c|c|c|c|c|c|c|c|c|c|c|c|}
\hline & & & & & & & & & & & & & & & & \\
\hline CC-101 & $3 / 27 / 02$ & 1535 & 6310 & 8.9 & 15.5 & 0.7 & 190 & 2.13 & 15.9 & 33.8 & 11 & 2.0 & 2.30 & 17.6 & 9.6 & 1760 \\
\hline CC-102 & $3 / 28 / 02$ & 1430 & 5290 & 5.3 & 15.1 & 0.6 & 150 & 2.24 & 14.2 & 39.6 & 8.3 & 1.7 & 2.13 & 15.5 & 7.5 & 1600 \\
\hline CC-103 & 3/28/02 & 1435 & 6060 & 5.7 & 15.7 & 0.6 & 180 & 2.34 & 16.7 & 43.5 & 9.9 & 1.8 & 2.17 & 16.6 & 9.1 & 1790 \\
\hline CC-104 & $3 / 29 / 02$ & 1740 & 7360 & 12.6 & 48.4 & 0.7 & 120 & 3.03 & 19.0 & 74.3 & 40 & 1.5 & 4.62 & 15.0 & 8.5 & 2430 \\
\hline MC-101 & $3 / 27 / 02$ & 1500 & 5410 & 1.0 & 23.3 & 0.4 & 110 & 2.01 & 13.6 & 52.8 & 6.8 & 0.84 & 5.59 & 4.4 & 8.7 & 711 \\
\hline MC-102 & $3 / 28 / 02$ & 1415 & 4770 & 2.0 & 23.8 & 0.4 & 100 & 2.44 & 11.3 & 238 & 7.4 & 0.80 & 4.88 & 4.4 & 7.2 & 633 \\
\hline MC-103 & $3 / 29 / 02$ & 1410 & 4360 & 2.0 & 25.1 & 0.3 & 91 & 2.61 & 9.59 & 92 & 8.9 & 0.78 & 3.82 & 4.3 & 6.2 & 581 \\
\hline MC-104 & $3 / 29 / 02$ & 1805 & 5220 & 4.2 & 26.1 & 0.4 & 83 & 2.65 & 9.06 & 115 & 14 & 0.76 & 4.19 & 4.6 & 6.0 & 545 \\
\hline UA-101 & $3 / 27 / 02$ & 1530 & 280 & $<1$ & 26.1 & 0.1 & 74 & 2.51 & 1.44 & 10.2 & 0.73 & 0.83 & 0.72 & 9.0 & 4.2 & 4000 \\
\hline UA-102 & 3/28/02 & 1430 & 364 & $<1$ & 25.7 & 0.1 & 74 & 2.76 & 2.00 & 12.3 & 1.1 & 0.93 & 0.88 & 9.4 & 4.3 & 5010 \\
\hline UA-103 & $3 / 29 / 02$ & 1720 & 366 & $<1$ & 23.2 & 0.2 & 65 & 2.73 & 1.72 & 18.7 & 1.1 & 1.2 & 1.21 & 7.8 & 3.6 & 3630 \\
\hline UA-104 & $3 / 29 / 02$ & 1715 & 386 & $<1$ & 23.5 & 0.2 & 66 & 2.68 & 1.76 & 17.6 & 1.2 & 1.2 & 1.24 & 7.8 & 3.6 & 3660 \\
\hline
\end{tabular}

Field No. date time Mo ug/L Na mg/L Ni ug/L P mg/L Pb ug/L Sc ug/L Si mg/L SO4 mg/L Sr ug/L Ti ug/L V ug/L Y ug/L Zn ug/L ICP-MS ICP-AES ICP-MS ICP-MS ICP-MS ICP-MS ICP-MS ICP-MS ICP-MS ICP-MS ICP-MS ICP-MS ICP-MS

\begin{tabular}{|c|c|c|c|c|c|c|c|c|c|c|c|c|c|c|c|}
\hline & & & & & & & & & & & & & & & \\
\hline CC-101 & $3 / 27 / 02$ & 1535 & 1.67 & 4.5 & 15.2 & 0.09 & 17.9 & 3.0 & 15.5 & 471 & 2030 & 10.1 & 4.0 & 8.90 & 705 \\
\hline CC-102 & $3 / 28 / 02$ & 1430 & 0.53 & 3.4 & 12.8 & 0.06 & 17.9 & 2.3 & 14.0 & 418 & 1850 & 6.7 & 2.9 & 8.09 & 636 \\
\hline CC-103 & 3/28/02 & 1435 & $<0.2$ & 4.1 & 14.2 & 0.07 & 19.0 & 2.4 & 13.9 & 521 & 1990 & 8.1 & 3.4 & 8.54 & 688 \\
\hline CC-104 & $3 / 29 / 02$ & 1740 & 0.35 & 3.1 & 13.8 & 0.40 & 49.5 & 3.2 & 12.6 & 378 & 1350 & 12.5 & 12.2 & 8.91 & 717 \\
\hline MC-101 & $3 / 27 / 02$ & 1500 & 0.35 & 5.1 & 7.2 & 0.02 & 14.1 & 1.6 & 9.1 & 278 & 983 & 3.8 & 1.0 & 12.5 & 564 \\
\hline MC-102 & 3/28/02 & 1415 & 0.6 & 4.8 & 6.7 & 0.03 & 24.1 & 1.6 & 8.2 & 240 & 907 & 3.8 & 1.0 & 10.3 & 652 \\
\hline MC-103 & 3/29/02 & 1410 & 0.59 & 4.3 & 5.9 & 0.04 & 28.9 & 1.5 & 8.2 & 226 & 836 & 3.7 & 1.1 & 8.54 & 696 \\
\hline MC-104 & $3 / 29 / 02$ & 1805 & 1.84 & 4.6 & 5.9 & 0.06 & 44.8 & 1.7 & 7.9 & 206 & 782 & 5.2 & 1.8 & 8.36 & 701 \\
\hline UA-101 & $3 / 27 / 02$ & 1530 & 2.08 & 2.8 & 3.3 & 0.01 & 6.6 & 0.7 & 4.1 & 149 & 695 & 3.8 & 0.2 & 0.70 & 690 \\
\hline UA-102 & 3/28/02 & 1430 & 3.36 & 2.8 & 3.8 & 0.01 & 7.6 & 0.8 & 4.3 & 190 & 744 & 3.9 & 0.2 & 0.95 & 758 \\
\hline UA-103 & 3/29/02 & 1720 & 1.42 & 2.7 & 3.4 & 0.04 & 11.1 & 0.8 & 3.6 & 128 & 607 & 3.1 & 0.2 & 1.25 & 749 \\
\hline UA-104 & $3 / 29 / 02$ & 1715 & 1.46 & 2.5 & 3.1 & 0.04 & 10.6 & 0.7 & 3.8 & 134 & 617 & 2.8 & 0.2 & 1.32 & 712 \\
\hline
\end{tabular}


Appendix 5. Quality control data for unfiltered water samples

collected from Animas River, Cement Creek, and Mineral Creek

near Silverton, Colorado, March 27-30, 2002

U.S. Geological Survey Open-File Report 02-0488

by D.L. Fey, L. Wirt, J.M. Besser, and W.G. Wright

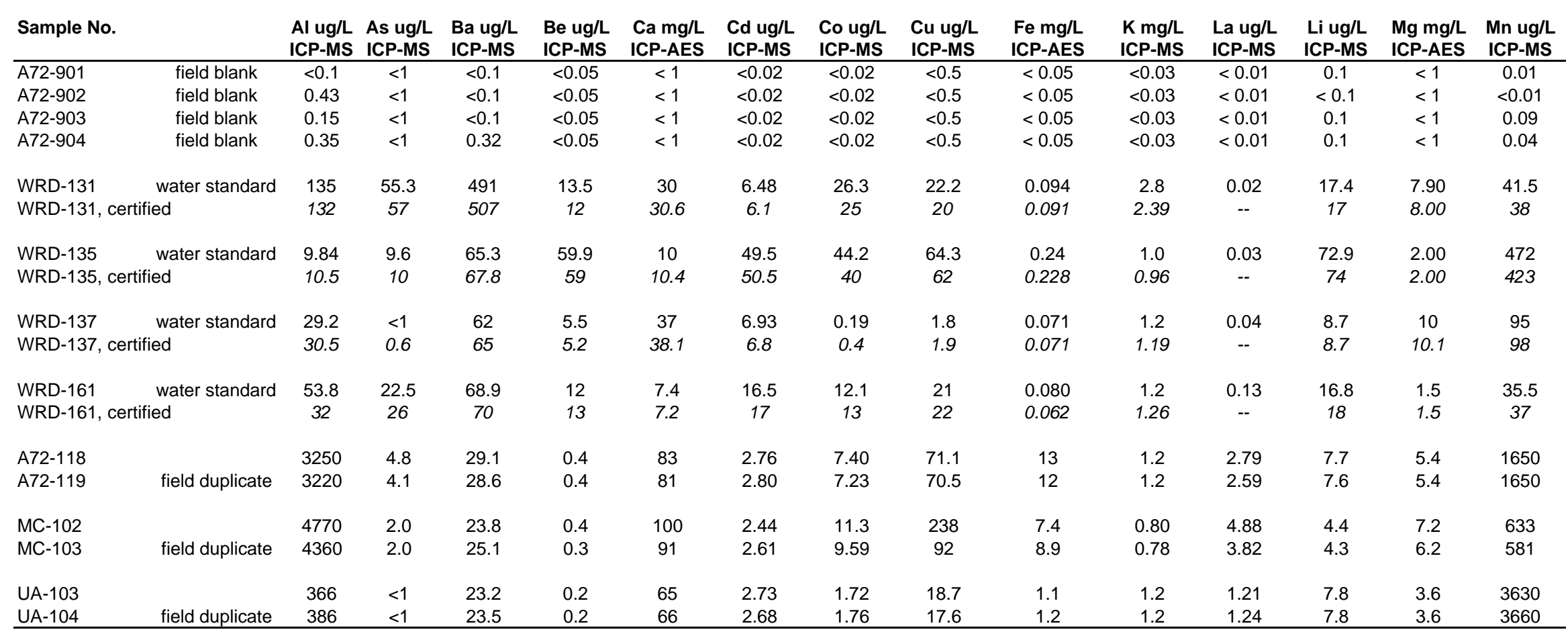


Appendix 5. Quality control data for unfiltered water samples

collected from Animas River, Cement Creek, and Mineral Creek

near Silverton, Colorado, March 27-30, 2002

contined

U.S. Geological Survey Open-File Report 02-0488

by D.L. Fey, L. Wirt, J.M. Besser, and W.G. Wright

\begin{tabular}{|c|c|c|c|c|c|c|c|c|c|c|c|c|c|c|}
\hline \multicolumn{2}{|l|}{ Sample No. } & \multirow{2}{*}{$\begin{array}{c}\text { Mo ug/L } \\
\text { ICP-MS }\end{array}$} & \multirow{2}{*}{$\begin{array}{c}\mathrm{Na} \mathrm{mg/L} \\
\text { ICP-AES } \\
<1\end{array}$} & \multirow{2}{*}{$\begin{array}{c}\begin{array}{c}\mathrm{Ni} \text { ug/L } \\
\text { ICP-MS }\end{array} \\
<0.1\end{array}$} & \multirow{2}{*}{$\begin{array}{c}\mathbf{P} \text { mg/L } \\
\text { ICP-MS } \\
<0.01\end{array}$} & \multirow{2}{*}{$\begin{array}{c}\begin{array}{c}\mathrm{Pb} \text { ug/L } \\
\text { ICP-MS }\end{array} \\
<0.05\end{array}$} & \multirow{2}{*}{$\begin{array}{c}\text { Sc ug/L } \\
\text { ICP-MS }\end{array}$} & \multirow{2}{*}{$\begin{array}{c}\text { Si mg/L } \\
\text { ICP-MS } \\
<0.2\end{array}$} & \multirow{2}{*}{$\begin{array}{c}\text { SO4 mg/L } \\
\text { ICP-MS }\end{array}$} & \multirow{2}{*}{$\begin{array}{c}\mathrm{Sr} \text { ug/L } \\
\text { ICP-MS } \\
<0.5\end{array}$} & \multirow{2}{*}{$\begin{array}{c}\mathrm{Ti} \text { ug/L } \\
\text { ICP-MS } \\
<0.1\end{array}$} & \multirow{2}{*}{$\begin{array}{c}\begin{array}{c}\text { V ug/L } \\
\text { ICP-MS }\end{array} \\
<0.1\end{array}$} & \multirow{2}{*}{$\begin{array}{c}\text { Y ug/L } \\
\text { ICP-MS } \\
<0.01\end{array}$} & \multirow{2}{*}{$\begin{array}{l}\begin{array}{c}\text { Zn ug/L } \\
\text { ICP-MS }\end{array} \\
<0.5\end{array}$} \\
\hline$\overline{A 72-901}$ & field blank & & & & & & & & & & & & & \\
\hline A72-902 & field blank & 0.59 & $<1$ & $<0.1$ & $<0.01$ & $<0.05$ & $<0.1$ & $<0.2$ & $<2$ & $<0.5$ & $<0.1$ & $<0.1$ & $<0.01$ & $<0.5$ \\
\hline A72-903 & field blank & $<0.2$ & $<1$ & $<0.1$ & $<0.01$ & $<0.05$ & $<0.1$ & $<0.2$ & $<2$ & $<0.5$ & $<0.1$ & $<0.1$ & $<0.01$ & $<0.5$ \\
\hline A72-904 & field blank & $<0.2$ & $<1$ & $<0.1$ & $<0.01$ & $<0.05$ & $<0.1$ & $<0.2$ & $<2$ & $<0.5$ & $<0.1$ & $<0.1$ & $<0.01$ & 2 \\
\hline WRD-131 & water standard & 113 & 21.0 & 62.6 & $<0.01$ & 16.3 & 0.8 & 3.3 & 2.0 & 291 & 0.2 & 39.5 & 0.02 & 73.8 \\
\hline \multicolumn{2}{|c|}{ WRD-131, certified } & 112 & 21.4 & 56 & -- & 18 & -- & -- & -- & 295 & -- & 34 & -- & 72 \\
\hline WRD-135 & water standard & 55.4 & 30.0 & 69.1 & 0.03 & 94.9 & 0.3 & 2.1 & 5.0 & 48.1 & 0.4 & 58.6 & 0.03 & 45.4 \\
\hline \multicolumn{2}{|c|}{ WRD-135, certified } & 63 & 30.8 & 65.6 & -- & 103 & -- & 2.0 & -- & 46 & -- & 52.8 & -- & 48.2 \\
\hline WRD-137 & water standard & 7.12 & 20.0 & 16 & 0.06 & 5.9 & 0.7 & 3.3 & 40 & 220 & 0.7 & 13.3 & 0.06 & 49.7 \\
\hline \multicolumn{2}{|c|}{ WRD-137, certified } & 8.9 & 22.0 & 15 & -- & 6.3 & -- & 3.24 & -- & 230 & -- & 14 & -- & 49.5 \\
\hline WRD-161 & water standard & 15.1 & 37 & 28 & $<0.01$ & 15.8 & 1.3 & 7.1 & 4 & 52 & 1.8 & 18.1 & 0.14 & 37 \\
\hline \multicolumn{2}{|c|}{ WRD-161, certified } & 19 & 43 & 29 & -- & 16 & -- & 6.9 & -- & 54 & -- & 18 & -- & 41 \\
\hline A72-118 & & 1.05 & 3.5 & 6.4 & 0.10 & 39.2 & 1.6 & 7.1 & 193 & 802 & 6.5 & 2.7 & 5.3 & 728 \\
\hline A72-119 & field duplicate & 0.67 & 3.4 & 6.2 & 0.10 & 34.4 & 1.6 & 7.1 & 195 & 807 & 5.6 & 2.5 & 5.3 & 795 \\
\hline MC-102 & & 0.6 & 4.8 & 6.7 & 0.03 & 24.1 & 1.6 & 8.2 & 240 & 907 & 3.8 & 1.0 & 10.3 & 652 \\
\hline MC-103 & field duplicate & 0.59 & 4.3 & 5.9 & 0.04 & 28.9 & 1.5 & 8.2 & 226 & 836 & 3.7 & 1.1 & 8.54 & 696 \\
\hline UA-103 & & 1.42 & 2.7 & 3.4 & 0.04 & 11.1 & 0.8 & 3.6 & 128 & 607 & 3.1 & 0.2 & 1.25 & 749 \\
\hline UA-104 & field duplicate & 1.46 & 2.5 & 3.1 & 0.04 & 10.6 & 0.7 & 3.8 & 134 & 617 & 2.8 & 0.2 & 1.32 & 712 \\
\hline
\end{tabular}


Appendix 6. Survival of amphipods (Hyalella azteca) and fathead minnows (Pimephales promelas) in serial dilutions of stream water collected at gage station A-72, Animas River below Silverton, March 22-27 (Test 1), March 28-29 (Test 2), and May 1-6 (Test 3). DWW=diluted well water; $A R W=$ Animas reconstituted water (control).

U.S. Geological Survey Open-File Report 02-0488

by D.L. Fey, L. Wirt, J.M. Besser, and W.G. Wright

\begin{tabular}{|c|c|c|c|c|c|c|c|}
\hline \multirow[t]{2}{*}{ Treatment } & \multirow[t]{2}{*}{ Replicate } & \multicolumn{3}{|c|}{ Amphipod survival (of 10 ) } & \multicolumn{3}{|c|}{ Minnow survival (of 10) } \\
\hline & & Test 1 & Test 2 & Test 3 & Test 1 & Test 2 & Test 3 \\
\hline DWW & 1 & 10 & 10 & 10 & 10 & 10 & 10 \\
\hline DWW & 2 & 10 & 10 & 10 & 10 & 9 & 9 \\
\hline DWW & 3 & 10 & 10 & 10 & 9 & 9 & 10 \\
\hline DWW & 4 & 10 & 10 & 10 & 10 & 10 & 9 \\
\hline DWW & 5 & 9 & 10 & 9 & & & \\
\hline DWW & 6 & 10 & 10 & 10 & & & \\
\hline ARW & 1 & 8 & 8 & 3 & 10 & 10 & 10 \\
\hline ARW & 2 & 8 & 8 & 2 & 10 & 8 & 9 \\
\hline ARW & 3 & 8 & 6 & 3 & 10 & 8 & 9 \\
\hline ARW & 4 & 9 & 8 & 3 & 9 & 10 & 8 \\
\hline ARW & 5 & 8 & 7 & 3 & & & \\
\hline ARW & 6 & 7 & 6 & 2 & & & \\
\hline A-72 12.5\% & 1 & 8 & 6 & 3 & 10 & 9 & 4 \\
\hline A-72 12.5\% & 2 & 9 & 9 & 2 & 10 & 10 & 2 \\
\hline A-72 12.5\% & 3 & 9 & 9 & 2 & 10 & 9 & 10 \\
\hline A-72 12.5\% & 4 & 8 & 6 & 3 & 9 & 10 & 10 \\
\hline A-72 12.5\% & 5 & 10 & 6 & 3 & & & \\
\hline A-72 12.5\% & 6 & 9 & 9 & 3 & & & \\
\hline A-72 25\% & 1 & 10 & 9 & 5 & 10 & 10 & 10 \\
\hline A-72 25\% & 2 & 9 & 8 & 5 & 9 & 10 & 8 \\
\hline A-72 25\% & 3 & 9 & 4 & 7 & 10 & 10 & 9 \\
\hline A-72 25\% & 4 & 8 & 7 & 4 & 8 & 10 & 9 \\
\hline A-72 25\% & 5 & 9 & 8 & 2 & & & \\
\hline A-72 25\% & 6 & 10 & 7 & 4 & & & \\
\hline A-72 50\% & 1 & 7 & 4 & 3 & 0 & 3 & 10 \\
\hline A-72 50\% & 2 & 9 & 7 & 4 & 0 & 4 & 9 \\
\hline A-72 50\% & 3 & 10 & 4 & 0 & 0 & 4 & 8 \\
\hline A-72 50\% & 4 & 10 & 1 & 8 & 0 & 4 & 10 \\
\hline A-72 50\% & 5 & 8 & 2 & 5 & & & \\
\hline A-72 50\% & 6 & 9 & 4 & 4 & & & \\
\hline A-72 100\% & 1 & 0 & 0 & 0 & 0 & 0 & 10 \\
\hline A-72 100\% & 2 & 0 & 0 & 0 & 0 & 0 & 10 \\
\hline A-72 100\% & 3 & 0 & 0 & 1 & 0 & 0 & 9 \\
\hline A-72 100\% & 4 & 0 & 0 & 0 & 0 & 0 & 10 \\
\hline A-72 100\% & 5 & 0 & 0 & 0 & & & \\
\hline A-72 100\% & 6 & 0 & 0 & 0 & & & \\
\hline
\end{tabular}

